\title{
Self-assembled network polymer electrolyte membranes for application in fuel cells at 250区
}

\section{Seungju Lee}

Korea Institute of Science and Technology

\section{YoungSuk Jo}

Korea Institute of Science and Technology

\section{Son-Jong Hwang}

California Institute of Technology

\section{Yongha Park}

Korea Institute of Science and Technology

\section{Yeong Cheon Kim}

Korea Institute of Science and Technology

\section{Tae Kyung Lee}

Korea Institute of Science and Technology

Hyoung-Juhn Kim

Korea Institute of Science and Technology

\section{Suk Woo Nam}

Korea Institute of Science and Technology

So Young Lee ( $\sim$ sylee5406@kist.re.kr)

Korea Institute of Science and Technology https://orcid.org/0000-0002-2003-5732

\section{Article}

Keywords: energy storage, energy conversion devices, polymer electrolyte membrane, fuel cells

Posted Date: September 7th, 2021

DOI: https://doi.org/10.21203/rs.3.rs-829052/v1

License: (c) (i) This work is licensed under a Creative Commons Attribution 4.0 International License.

Read Full License 


\section{Self-assembled network polymer electrolyte membranes}

\section{2 for application in fuel cells at $250{ }^{\circ} \mathrm{C}$}

3 Seungju Lee ${ }^{1, \dagger}$, YoungSuk Jo ${ }^{1, \dagger}$, Son-Jong Hwang ${ }^{2}$, Yongha Park ${ }^{1}$, Yeong Cheon Kim ${ }^{1}$, Tae

4 Kyung Lee ${ }^{1}$, Hyoung-Juhn $\mathrm{Kim}^{1 *}$, Suk-Woo Nam, ${ }^{1 *}$ and So Young Lee ${ }^{1 *}$

5

$6 \quad{ }^{1}$ Hydrogen·Fuel Cell Research Center, Korea Institute of Science and Technology, 5,

$7 \quad$ Hwarangro 14-gil, Seongbuk-gu, Seoul 02792, Republic of Korea

$8{ }^{2}$ Division of Chemistry and Chemical Engineering, California Institute of Technology,

9 Pasadena, California 91125, USA

10

11 *Corresponding authors:

S. Y. Lee (Email: sylee5406@kist.re.kr)

S. W. Nam (Email: $\underline{\text { swn@ @ist.re.kr) }}$

14

H. -J. Kim (Email: hjkim25@kist.re.kr) 
22 Modern $\mathrm{H}_{2}$-based energy storage and conversion devices require a polymer electrolyte membrane (PEM) fuel cell-based integrated power system with synergistic heat integration. The key issue in integrated power systems is developing a PEM that can operate at $200-300{ }^{\circ} \mathrm{C}$. However, currently used phosphoric-acid-based high-temperature PEM fuel cells limited stability at higher operating temperatures. Herein, we introduce a cerium hydrogen phosphate (CeHP) PEM that conducts protons above $200{ }^{\circ} \mathrm{C}$ through a self-assembled network (SAN). The SAN-CeHP-PBI reached maximum power densities of $2.4 \mathrm{~W} \mathrm{~cm}^{-2}$ and operate stably for over 7000 minute without any voltage decay at $250{ }^{\circ} \mathrm{C}$ under $\mathrm{H}_{2} / \mathrm{O}_{2}$ and anhydrous conditions. The developed fuel cell can be combined with an external hydrogen generator that uses a liquid hydrogen carrier such as $\mathrm{N}$-ethylcarbazole and methanol as fuel, thus achieving a high energy efficiency. The thermal stability and fuel flexibility of these SAN-CeHP-PBI demonstrate potential for commercial applications. 
Climate change and growing environmental concerns have increased the demand for clean, renewable energy sources. hydrogen is considered as one of the most promising sources and hydrogen fuel cells efficiently convert chemical energy into electrical energy ${ }^{1}$. Particularly, low-temperature proton exchange membrane fuel cells (LT-PEMFCs) using perfluorosulfonic acid membranes are appealing alternative power devices for transportation applications because of their low noise, high power density, and long driving distance with a single charge of hydrogen. However, issues such as the demand for high-purity fuel $\left(\mathrm{H}_{2}\right)$, cost, lack of membrane and electrode durability, and complicated water management in the electrochemical system hinder the commercialization of proton exchange membrane fuel cells (PEMFCs) ${ }^{2,3}$. By contrast, high-temperature proton exchange membrane fuel cells (HT-PEMFC) can operate at $140-180{ }^{\circ} \mathrm{C}$ and offer several advantages such as significantly enhanced reaction kinetics, high power output, enhanced CO tolerance, and relatively simple water management ${ }^{4-}$ ${ }^{6}$. However, the most promising HT-PEMFC based on a phosphoric acid (PA)-doped polybenzimidazole (PBI) membrane showed limited long-term stability up to $180{ }^{\circ} \mathrm{C}$ and exhibited unsatisfactory cell performance with a maximum power density of $\sim 0.5 \mathrm{~W} \cdot \mathrm{cm}^{-2}$ at $160{ }^{\circ} \mathrm{C}^{7,8}$. As PA is used as an electrolyte, proton conduction is not possible owing to the leakage of PA or the formation of phosphoric anhydride at higher operating temperatures ${ }^{9,10}$. The suboptimal cell performance and limited operating temperature range make it difficult to adopt such cells for a variety of applications.

The purpose of this study is to develop polymer electrolyte membranes that operate at temperature range of $200-250^{\circ} \mathrm{C}$. In this temperature range, extraction of hydrogen from liquid hydrogen carriers (LHCs) such as methanol and N-ehthylcarbazole is possible within the fuel cell, which improves fuel cell efficiency. These liquid hydrogen carriers lead to a high 
volumetric energy density and are compatible with the current fuel storage and transport infrastructure $^{11,12}$, solving problems of the physical hydrogen storage methods.

We consider solid acids promising candidates for use as HT-PEMFC electrolytes working at an integrated high-temperature range $\left(200-300{ }^{\circ} \mathrm{C}\right)$. Many research groups have tried to increase the operating temperature of PEMFCs. The majority of the groups have been developing composite membranes to reduce the evaporation of the electrolyte PA at high temperatures ${ }^{13-15}$. Another group has developed ion-pair-coordinated membrane electrode assemblies focusing on the binder rather than the electrolyte ${ }^{16-18}$. Nevertheless, the key challenge in attaining optimal and stable fuel cell performance is stabilizing the proton carrier at temperatures higher than $200^{\circ} \mathrm{C}$. Herein, we report a proton conductor, unique nanofibrous cerium hydrogen phosphate $\left(\mathrm{CeHP},\left(\mathrm{HCe}_{2}\left(\mathrm{PO}_{4}\right)_{3}\left(\mathrm{H}_{2} \mathrm{O}\right)\right)\right)$ immobilized in a $\mathrm{PBI}$ polymer electrolyte, which can overcome the limitations of the state-of-the-art PA-based PEM electrolytes, thereby enabling fuel cell operation over $250^{\circ} \mathrm{C}$. These PEMs can transfer protons through a nanofibrous CeHP network. Notably, the novel membranes have a nanofibrous CeHP network chemically bound to the PBI backbone, resulting in the formation of the hydrogen bond network through which the structural diffusion of protons becomes possible. We evaluated the performance and durability of the novel membrane in the temperature range 150 $250{ }^{\circ} \mathrm{C}$. In particular, the significantly improved $\mathrm{CO}$ tolerance at high temperatures enables the use of low-purity hydrogen and reformate gases from hydrogen carriers such as methanol and dimethyl ether (DME) through external reforming ${ }^{19-22}$. Additionally, we have been developing couplings between the $\mathrm{H}_{2}$ extraction reaction and the electrochemical reaction of a fuel cell by utilizing fuels such as LHCs. As a proof of concept, we evaluated the performance of integrated fuel processor-fuel cells using $\mathrm{H}_{2}$ from the dehydrogenation of hydrogenated $\mathrm{N}$-ethylcarbazole and methanol reforming. 


\section{Self-assembled network PBI membrane fabrication}

We synthesized a self-assembled network (SAN) polymer electrolyte membrane using nanofibrous CeHP as a proton conductor through an in-situ sol-gel process (the membranes are denoted as SAN-CeHP-PBI). The in-situ sol-gel process allows the simple one-pot and lowcost fabrication of large-area membranes ${ }^{23}$. CeHP is a unique insoluble acid salt of a tetravalent metal that forms a nanofibrous structure when it is in the phosphate form ${ }^{24-26}$ (Supplementary Discussion 1, Extended Data Fig. 1a and 1b). When CeHP powder is mixed with concentrated PA, it shows solvation behavior, similar to an ionomer (Supplementary Discussion 1, Extended data Figure 2). To synthesize SAN-CeHP-PBI, the CeHP (IV) precursor solution was added during the termination process of $p$-PBI polymer synthesis ${ }^{27}$ (Fig. 1a). The Ce (IV) ions of the added Ce precursor were evenly dispersed in the polymer solution, serving as a nucleus for the formation of a crystal in the polymer. This mixed Ce precursor and p-PBI polymer solution were applied to a glass plate, and the electrolyte membrane was prepared by the doctor blade method. Subsequently, water was released during the hydrolysis of the mixed Ce precursor and $p$-PBI electrolyte membrane in the humidified chamber oven, converting polyphosphoric acid to $\mathrm{PA}$ and producing nanofibrous $\mathrm{CeHP}$ from $\mathrm{Ce}$ (IV) ions in the $p$-PBI polymer. Thus, as CeHP and $p$-PBI were synthesized simultaneously, the nanofibrous CeHP structure formed a SAN that stably bound to the $p$-PBI polymer. The results indicate that structural surface diffusion of the proton can be possible within the hydrogen bond network of the SAN-CeHP-PBI polymer.

\section{Working principle of PA-doped SAN-CeHP-PBI}

The excess PA-doped SAN-CeHP-PBI composite membranes dominantly follow the PA proton transfer mechanism: a Grotthuss-type hopping mechanism below $180^{\circ} \mathrm{C}^{10,28}$ (Fig. 1b). Above $200{ }^{\circ} \mathrm{C}$, the SAN polymer electrolyte membrane becomes thinner due to the 
condensation reaction and leaching of PA and water from the composite membranes doped with excess PA(Extended Data Fig. 3a, 3b). The elevated operating temperature results in forming an amorphous $\mathrm{CeH}_{x} \mathrm{PO}_{4}(\mathrm{OH})_{y}$ structure with a small amount of remaining PA and crystalline CeHP. Consequently, the $\mathrm{CeH}_{x} \mathrm{PO}_{4}(\mathrm{OH})_{y}$ generated between the hydrogen bond network of the SAN-CeHP-PBI polymer formed more closely connected SANs, and structural diffusion sites were created above $200{ }^{\circ} \mathrm{C}($ Fig. 1c). The dominant proton conduction pathway changed from the PA electrolyte to surface/interfacial conduction in the SAN of the CeHP-PBI polymer, and the concentrated PA-CeHP mixtures held the PA molecules because of better adhesion at the acid/acid salt interface ${ }^{11,15}$ (see Extended Data Fig.4). We fabricated membrane electrode assemblies (MEAs) using the SAN-CeHP-PBI membrane, carbon-supported Pt catalysts, and PTFE binder. The single cell was operated at $150-250{ }^{\circ} \mathrm{C}$ using $\mathrm{H}_{2} / \mathrm{O}_{2}$, and it was found that the performance increased with increasing temperature, with the SAN polymer electrolyte membrane exhibiting a maximum peak power density of $2.4 \mathrm{~W} \cdot \mathrm{cm}^{-2}$ at $250{ }^{\circ} \mathrm{C}$ (Fig. 1d and Extended Data Fig. 3c). This is the best performance obtained among the state-of-the-art fuel cells capable of operating at $200-300{ }^{\circ} \mathrm{C}$, as shown in Fig. 1e and the Extended Data Table. $\mathbf{1}^{2,13-16,29-39}$.

\section{Property comparison for three type of PA-doped PBI membranes}

We compare the properties of three types of PA-doped PBI membranes $\left(p-\mathrm{PBI}^{27}\right.$ : the pristine membrane that does not contain Ce, CeHP-PBI, and SAN-CeHP-PBI). The CeHP-PBI composite membrane was prepared by the conventional ex-situ method of adding a CeHP nanoparticle powder solution in the $p$-PBI polymer solution ${ }^{40,41}$ (the membranes are denoted as CeHP-PBI). The CeHP nanoparticle powder in PA added during polymerization does not change significantly upon the chemical bonding of polymers even during hydrolysis ${ }^{10}$ (Extended Data Fig. 5 and Table. 2), and CeHP nanoparticle are disparate in the PA-doped 
PBI polymer (Fig. 2a). When the temperature is below $200{ }^{\circ} \mathrm{C}$, fuel cells with composite membranes doped with excess PA showed higher performance than those prepared with PAdoped pristine p-PBI. Further, protons are conducted by the Grotthuss mechanism through PA (Fig. 2a and 2b). However, the excess PA disappears at temperatures above $200{ }^{\circ} \mathrm{C}$, and in the SAN-CeHP-PBI, proton conduction occurs by surface/interfacial conduction and structural diffusion through the SAN of CeHP caused by water molecules and PA bound to CeHP. By contrast, in CeHP-PBI, proton conduction is limited because protons are transported to the dispersed CeHP, which does not form a close network for proton conduction (Fig. 2c, 2d and Extended Data Fig. 4). As the operating temperature increases, PA is removed from the polymer, and SEM analysis confirmed the appearance of an amorphous $\mathrm{CeH}_{\mathrm{x}} \mathrm{PO}_{4}(\mathrm{OH})_{\mathrm{y}}$ and $\mathrm{CeHP}$ structure in the CeHP-PBI and SAN-CeHP-PBI membranes. Notably, SAN-CeHP-PBI shows more connected nanofibrous structures than those of CeHPPBI (Extended Data Fig. 2 and 5a-d).

We compared the proton conductivities of three types of PA-dope PBI membranes under dry conditions as a function of temperature. The proton conductivity of $p-\mathrm{PBI}$ is unmeasurable above $200{ }^{\circ} \mathrm{C}$ and does not change notably within the temperature range employed in this study. The proton conductivity of CeHP-PBI increased with increasing temperature up to $200{ }^{\circ} \mathrm{C}$ and then decreased with further temperature increase because of the absence of proton conducting channels ${ }^{11,42,43}$. Unlike the other two membranes, the proton conductivity of SAN-CeHP-PBI gradually increased with increasing temperature and reached $0.257 \mathrm{~S} \cdot \mathrm{cm}^{-}$ ${ }^{1}$ at $280{ }^{\circ} \mathrm{C} \quad$ (Fig. 2e). In addition, the trend of the high ionic conductivity of SAN-CeHPPBI can be confirmed with Raman analysis. The Raman spectra of bare SAN-CeHP-PBI displayed a peak at $911 \mathrm{~cm}^{-1}$ corresponding to free PA at $30^{\circ} \mathrm{C}$. In the PA-removed de-doped sample, SAN-CeHP-PBI demonstrated a peak at $1632 \mathrm{~cm}^{-1}$ at the $\gamma$ part of the benzimidazole 
ring of the polymer backbone part. This indicates that in the polymer benzimidazole ring, CeHP is attached to N-H through hydrogen bonding (Extended Data Fig. 5e-f and Table. $2)^{10}$. Further, the combination of polymer-CeHP and CeHP-CeHP network channels in the SAN-CeHP-PBI composite membranes enhances the tensile toughness, which is $\sim 2.5$ times (SAN-CeHP-PBI: $3.5 \mathrm{Mpa}$ and de-doped SAN-CeHP-PBI: $125 \mathrm{Mpa}$ ) higher than that of pristine $p$-PBI ( $p$-PBI: 1.4 Mpa and de-doped $p$-PBI: $50 \mathrm{Mpa}$ ) (Extended Data Fig. 6).

The single-cell performances of three different types of PA-doped membranes were compared under $\mathrm{H}_{2}$ /air conditions without humidification at atmospheric pressure and 150 $250{ }^{\circ} \mathrm{C}$, and the results are shown in Fig. $2 \mathbf{f}-\mathbf{h}$. These membrane electrode assemblies (MEAs) were fabricated by applying commercial BASF electrodes. The fuel cell containing the pristine $p$-PBI membrane could not operate above $200^{\circ} \mathrm{C}$, while the cell containing the CeHPPBI composite membrane exhibited the maximum power densities $0.93 \mathrm{~W} \cdot \mathrm{cm}^{-2}$ and 0.91 $\mathrm{W} \cdot \mathrm{cm}^{-2}$ at $200{ }^{\circ} \mathrm{C}$ and $250{ }^{\circ} \mathrm{C}$, respectively. The CeHP-PBI showed the highest performance at $200{ }^{\circ} \mathrm{C}$. By contrast, the performance of the cell with the SAN-CeHP-PBI composite membrane improved with an increase in temperature to $250{ }^{\circ} \mathrm{C}$. The SAN-CeHP-PBI composite membrane exhibited the best performance at $250{ }^{\circ} \mathrm{C}$ with the maximum power density of $1.2 \mathrm{~W} \cdot \mathrm{cm}^{-2}\left(1.1 \mathrm{~W} \cdot \mathrm{cm}^{-2}\right.$ at $\left.200^{\circ} \mathrm{C}\right)$.

NMR spectroscopic analysis can explain the difference in proton conduction behavior between p-PBI, CeHP-PBI, and SAN-CeHP-PBI membranes. The solid-state ${ }^{31} \mathrm{P}$ NMR spectra of the three membranes enriched with excess PA exhibit peaks corresponding to $\mathrm{H}_{3} \mathrm{PO}_{4}, \mathrm{HPO}_{4}{ }^{2-}$, and $\mathrm{PO}_{4}{ }^{3-}$ at $0,-14$, and -28 ppm, respectively, at $150-280{ }^{\circ} \mathrm{C}$ (Fig. 2i, 2j, and $2 \mathbf{k})^{44-46}$. The samples show progressive peak broadening with increasing temperature, which is attributed to the exchange of $\mathrm{H}^{+}$ions (or $\mathrm{H}^{+}$hopping) among the three different phosphate phases. The three resonances would merge into a single resonance when the 
hopping rate increases over the NMR observation time scale, which is of the order of milliseconds. For $p$-PBI and CeHP-PBI, peak broadening was observed until $200{ }^{\circ} \mathrm{C}$, beyond which, interestingly, the peaks sharpened, indicating interference in proton conduction above $200{ }^{\circ} \mathrm{C}$ (Fig. $2 \mathbf{i}$ and $\mathbf{2 j}$ ). On the other hand, peak broadening continued until $280{ }^{\circ} \mathrm{C}$ only in SAN-CeHP-PBI as $\mathrm{H}^{+}$ion hopping continued to rise at high temperatures (Fig. 2k). Moreover, we analyzed de-doped membranes by solid-state ${ }^{31} \mathrm{P}$ NMR analysis, where excessive PA was discarded from the membrane to leave only PA units that are tied with the electrostatic bonding to the PBI polymer chains. The NMR analysis results indicate the proton transfer phenomenon for SAN-CeHP-PBI, from which PA was removed under high-temperature conditions. Typically, the removal of excess phosphoric acid results in the formation of pyrophosphoric acid, which interferes with proton conduction. Unlike in $p$-PBI and CeHPPBI, pyrophosphoric acid was not formed until $270{ }^{\circ} \mathrm{C}$, and only the $\mathrm{Ce}\left(\mathrm{PO}_{4}\right)_{2}$ peak appeared in SAN-CeHP-PBI. This may be due to the mobility of the polymer matrix at high temperatures, which was beneficial to the transport of the $\mathrm{H}^{+}$ions in the structure (Extended Data Fig. 7 Supplementary Discussion 2). The de-doped SAN-CeHP-PBI composite membrane was re-doped, and its single cell performance was tested to see the reversibility of PA doping. Although re-doped SAN-CeHP-PBI exhibited a lower performance due to the change in PA acid doping level (PA-doped 40 PA/PBI RU to re-doped $32 \mathrm{PA} / \mathrm{PBI}$ RU), the performance was stable for 5,000 min. The strong bond between the synthesized SAN-CeHP channel and PBI is not dissociated by PA leakage (Extended Data Fig. 8).

\section{Effect of Ce content for SAN-CeHP-PBI membranes}

We synthesized membranes with $0-90 \mathrm{wt} \%$ Ce content compared to the polymer monomer to optimize SAN channel formation. The CeHP structures and the degree of crystallinity depend on the concentration of solutions containing a $\mathrm{Ce}(\mathrm{IV})$ salt and the $\left[\mathrm{PO}_{4} / \mathrm{Ce}(\mathrm{IV}) \text { ratio }\right]^{25,26}$. 
212 Figure 3a shows SEM images of the networking morphology of SAN-CeHP-PBI membranes according to different contents of $\mathrm{Ce}$. The larger the Ce content, the larger the crystal size due to the agglomeration of Ce molecules. However, if the amount of $\mathrm{Ce}$ is $70 \mathrm{wt} \%$ or more for the same PA solution, the proportion of $\mathrm{PO}_{4}{ }^{3-}$ that can react with the $\mathrm{Ce}(\mathrm{IV})$ precursor becomes relatively small. Therefore, as the amount of Ce exceeds $70 \mathrm{wt} \%$, crystalline growth by nucleation becomes limited, and a non-fibrous morphology and smaller and widely distributed crystalline size are observed. At $35 \mathrm{wt} \%$ Ce content, a semi-crystalline polymer with a dense fibrous self-assembled network structure was formed by the growth of spherulites from the crystalline nuclei derived from the Ce precursor (Fig. 3a). The acid doping level of $35 \mathrm{wt} \%$ SAN-CeHP-PBI is $40 \mathrm{~mol} \mathrm{H}_{3} \mathrm{PO}_{4} / \mathrm{PBI}$ repeat unit, which is 1.6 times higher than those of conventional PA-doped $p$-PBI and CeHP-PBI (27.7 and 26 PA/PBI RU). Additionally, NMR quantitation of ${ }^{31} \mathrm{P}$ signals of the $\mathrm{H}_{3} \mathrm{PO}_{4}, \mathrm{HPO}_{4}{ }^{2-}$, and $\mathrm{PO}_{4}{ }^{3-}$ phases normalized by the weight of all the samples was performed, and the highest NMR quantitation was obtained for the membrane with $35 \mathrm{wt} \%$ Ce content (Fig. 3b). The hopping effect of protons was the highest in $15 \mathrm{wt} \%$ SAN-CeHP-PBI (Fig. 3c), but the mechanical strength of $35 \mathrm{wt} \%$ SAN-CeHP-PBI was superior to that of other composite membranes owing to the close interactions corresponding to crystalline CeHP (Fig. 3d and 3e).

\section{Fuel cell performances and durability}

The best $\mathrm{H}_{2}$ /air fuel cell performance was achieved with $35 \mathrm{wt} \% \mathrm{SAN}-\mathrm{CeHP}-\mathrm{PBI}$ at $250{ }^{\circ} \mathrm{C}$, with a maximum power density of $1.16 \mathrm{~W} \cdot \mathrm{cm}^{-2}$ (Extended Data Fig. 9a-c). This is attributed to the proton transfer channels formed by the dense fibrous morphology of CeHP. We prepared with MEAs using optimized 35 wt $\%$ SAN-CeHP-PBI membranes, carbon-supported Pt catalysts, and PTFE binder. CO tolerance tests were conducted by supplying $\mathrm{H}_{2} /$ air or a mixture of $10 \% \mathrm{CO}$ and $\mathrm{H}_{2}$ /air to the anode at different temperatures, and the fuel cell voltage was 
recorded at a constant current density of $0.2 \mathrm{~A} \cdot \mathrm{cm}^{-2}$ for 2,250 min. As shown in Fig. 3f, the voltage slightly decreased from 0.78 at $250{ }^{\circ} \mathrm{C}$ to $0.71 \mathrm{~V}$ at $160^{\circ} \mathrm{C}$. This improved $\mathrm{CO}$ tolerance of the $35 \mathrm{wt} \%$ SAN-CeHP-PBI membranes allows the direct use of the reformation of liquid fuels. The long-term durability test of $35 \mathrm{wt} \%$ SAN-CeHP-PBI MEAs was performed at 0.2 $\mathrm{A} \cdot \mathrm{cm}^{-2}$ and $250{ }^{\circ} \mathrm{C}$ under $\mathrm{H}_{2} /$ air conditions, showing a highly stable performance for 7,000 min at $250{ }^{\circ} \mathrm{C}$ (Fig. 3g). Electrochemical impedance spectroscopy (EIS) was performed at $0.85 \mathrm{~V}$ and $0.6 \mathrm{~V}$, respectively, to compare the performances of $35 \mathrm{wt} \%$ SAN-CeHP-PBI MEAs before and after the durability test. The ohmic resistances $\left(0.013 \Omega \cdot \mathrm{cm}^{2}\right.$ to $\left.0.018 \Omega \cdot \mathrm{cm}^{2}\right)$ at $0.85 \mathrm{~V}$ and $0.6 \mathrm{~V}$ are similar before and after the durability test, whereas the charge transfer resistance is increased slightly after the durability test ${ }^{47}$ (Extended Data Fig. 10). This indicates that MEA degradation is caused by the electrode degradation (especially, Pt/C and PTFE binder) rather than the PEM at a high operating temperature of $250{ }^{\circ} \mathrm{C}$ over a long period ${ }^{48}$. Therefore, catalysts and binders that are stable in the operating temperature ranges must be developed for long-term HT-PEMFCs operating at $200-300{ }^{\circ} \mathrm{C}$. demonstrated the viability of an ideal direct LHC fuel cell concept (see Supplementary

Discussion 3). However, in a single cell, it is difficult to experimentally demonstrate the effects of heat and mass transfer integration, as heat loss is larger than exchanged heat. Therefore, external reforming was demonstrated by physically attaching the reforming unit to the single cell while maintaining the same temperature for the fuel cell and the reformer to simulate a heat-integrated configuration (Extended Data Fig. 11c and 11d). We compared the fuel cell performances of pure $\mathrm{H}_{2}$ and as-produced $\mathrm{H}_{2}$ from the reformer by varying the flow rate of a small-scale single cell. First, an N-ethylcarbazole (NEC) dehydrogenation external reformer 
was built that was operated in conjunction with the single cell. No difference in performance (power density: $0.5 \mathrm{~W} \cdot \mathrm{cm}^{-2}$ ) was observed, as expected. The result is encouraging with regards to the feasibility of heat management based on integration, and thus, the viability of a directLHC fuel cell (Fig. 4a). Second, methanol was used to benchmark the performance of the fuel cell. The composition of the fuel provided to the anode was varied: $100 \%$ pure $\mathrm{H}_{2}, 50 \%$ pure $\mathrm{H}_{2}$, and $50 \%$ off-gas, and $100 \%$ off-gas from the external reformer. The performances of the fuel cells using three different fuel compositions were almost the same (power density: 0.82 $\mathrm{W} \cdot \mathrm{cm}^{-2}$ ) (Fig. 4b), which shows the viability of external methanol reforms coupled with the developed fuel cell. Moreover, at $250{ }^{\circ} \mathrm{C}$, high conversion of methanol (>90\%) was achieved. Finally, long-term durability experiments were conducted to determine whether the external reforming of methanol is a viable option to provide $\mathrm{H}_{2}$-rich fuel containing $\mathrm{CO}$. The results showed that the external reforming methanol fuel cell is stable under $3 \% \mathrm{CO}$ and $0.5 \mathrm{~A} \cdot \mathrm{cm}^{-2}$ for $1200 \mathrm{~min}$ at $250{ }^{\circ} \mathrm{C}$ (Fig. 4c). The SAN-CeHP-PBI-based PEMFC combined with the reformed LHC fuel demonstrated exceptional CO tolerance and long-term durability at $250{ }^{\circ} \mathrm{C}$. Moreover, it highlighted that this technology is promising and has the potential for commercial application. We suggest a conceptual direct LHC system, extending the range of heavy-duty trucks powered with integrated HT-PEMFC stacks fueled by LHCs, in contrast with fueling by $\mathrm{H}_{2}$ gas tanks. Based on the preliminary integration work presented in this paper, the combined fuel processor and fuel cell is expected to be a promising device for solving energy density and infrastructural problems related to compressed $\mathrm{H}_{2}{ }^{49}$ (Fig. 4d).

\section{Conclusions}

In summary, we developed HT-PEMFCs based on a new type of proton carrier, SAN-CeHPPBI PEMs, in which proton conduction occurs through a self-assembled network of CeHP. At operating temperatures above $180^{\circ} \mathrm{C}$, the dominant proton conduction pathway changed from 
the PA electrolyte to surface/interfacial conduction in the SAN CeHP-PBI polymer, thereby overcoming the limitations of PA-based PEM electrolytes and enabling operation at $250{ }^{\circ} \mathrm{C}$. The SAN-CeHP-PBI membrane exhibited the best performance among all the excellent fuel cells operating at $250{ }^{\circ} \mathrm{C}$ reported so far, as well as excellent $\mathrm{CO}$ tolerance, thus showing great promise for high-performance integration energy applications at high temperatures (up to $\left.280{ }^{\circ} \mathrm{C}\right)$. The SAN-CeHP-PBI membranes afford an integrated fuel cell-internal reforming system that can be applied to mobility solutions. This shows the feasibility of heat integration and the viability of a direct-LHC fuel cell and its potential for commercial application. Other challenges are developing stable catalysts and binders to withstand long-term operation and exposure to temperatures above $250{ }^{\circ} \mathrm{C}$.

\section{References}

1 Lemmon, J. P. Energy: Reimagine fuel cells. Nature News 525, 447 (2015).

2 Park, C. H. et al. Nanocrack-regulated self-humidifying membranes. Nature 532, 480483 (2016).

3 Steele, B. C. \& Heinzel, A. in Materials for sustainable energy: a collection of peerreviewed Research and review articles from nature publishing group 224-231 (World Scientific, 2011).

4 Alberti, G., Casciola, M., Massinelli, L. \& Bauer, B. Polymeric proton conducting membranes for medium temperature fuel cells (110-160 C). Journal of Membrane Science 185, 73-81 (2001).

5 Li, Q., He, R., Jensen, J. O. \& Bjerrum, N. J. Approaches and recent development of polymer electrolyte membranes for fuel cells operating above $100 \mathrm{C}$. Chemistry of materials 15, 4896-4915 (2003). 
3086 Zhang, J. et al. High temperature PEM fuel cells. Journal of power Sources 160, 872$309891(2006)$

3107 Moçotéguy, P. et al. Long-Term Testing in Dynamic Mode of HT-PEMFC H3PO4/PBI 311 Celtec-P Based Membrane Electrode Assemblies for Micro-CHP Applications. Fuel $312 \quad$ Cells 10, 299-311 (2010).

3138 Yu, S., Xiao, L. \& Benicewicz, B. Durability studies of PBI-based high temperature $314 \quad$ PEMFCs. Fuel Cells 8, 165-174 (2008).

3159 Schuster, M., Rager, T., Noda, A., Kreuer, K. \& Maier, J. About the choice of the 316 protogenic group in PEM separator materials for intermediate temperature, low 317 humidity operation: a critical comparison of sulfonic acid, phosphonic acid and 318 imidazole functionalized model compounds. Fuel Cells 5, 355-365 (2005).

31910 Melchior, J.-P., Majer, G. \& Kreuer, K.-D. Why do proton conducting polybenzimidazole phosphoric acid membranes perform well in high-temperature PEM fuel cells? Physical Chemistry Chemical Physics 19, 601-612 (2017).

32211 Zhang, J., Xiang, Y., Lu, S. \& Jiang, S. P. High temperature polymer electrolyte critical review. Advanced Sustainable Systems 2, 1700184 (2018).

12 Papavasiliou, J., Avgouropoulos, G. \& Ioannides, T. CuMnOx catalysts for internal

$13 \mathrm{Li}, \mathrm{X}$. et al. Construction of high-performance, high-temperature proton exchange 329 membranes through incorporating $\mathrm{SiO} 2$ nanoparticles into novel cross-linked polybenzimidazole networks. ACS applied materials \& interfaces 11, 30735-30746 (2019). 
33214 Lobato, J., Canizares, P., Rodrigo, M. A., Úbeda, D. \& Pinar, F. J. Enhancement of the fuel cell performance of a high temperature proton exchange membrane fuel cell running with titanium composite polybenzimidazole-based membranes. Journal of Power Sources 196, 8265-8271 (2011).

15 Zhang, J. et al. In situ formed phosphoric acid/phosphosilicate nanoclusters in the exceptional enhancement of durability of polybenzimidazole membrane fuel cells at elevated high temperatures. Journal of the Electrochemical Society 164, F1615 (2017).

16 Lee, K.-S. et al. Intermediate temperature fuel cells via an ion-pair coordinated polymer electrolyte. Energy \& Environmental Science 11, 979-987 (2018).

17 Lee, K.-S., Spendelow, J. S., Choe, Y.-K., Fujimoto, C. \& Kim, Y. S. An operationally flexible fuel cell based on quaternary ammonium-biphosphate ion pairs. Nature energy 1, 1-7 (2016).

Atanasov, V. et al. Synergistically integrated phosphonated poly (pentafluorostyrene) for fuel cells. Nature Materials 20, 370-377 (2021).

19 Orfanidi, A., Daletou, M. K. \& Neophytides, S. G. Mitigation strategy towards stabilizing the Electrochemical Interface under high $\mathrm{CO}$ and $\mathrm{H} 2 \mathrm{O}$ containing reformate gas feed. Electrochimica Acta 233, 218-228 (2017).

Geormezi, M. et al. The structure and stability of the anodic electrochemical interface in a high temperature polymer electrolyte membrane fuel cell under reformate feed. Journal of Power Sources 285, 499-509 (2015).

21 Zhang, C., Zhou, W., Ehteshami, M. M., Wang, Y. \& Chan, S. H. Determination of the optimal operating temperature range for high temperature PEM fuel cell considering its performance, $\mathrm{CO}$ tolerance and degradation. Energy conversion and management $\mathbf{1 0 5}$, 433-441 (2015). 
35622 Li, Q., He, R., Gao, J.-A., Jensen, J. O. \& Bjerrum, N. J. The CO poisoning effect in PEMFCs operational at temperatures up to 200 C. Journal of the Electrochemical Society 150, A1599 (2003).

23 Xiao, L. et al. High-temperature polybenzimidazole fuel cell membranes via a sol- gel process. Chemistry of Materials 17, 5328-5333 (2005).

24 Alberti, G., Constantino, U., Di Gregorio, F., Galli, P. \& Torracca, E. Crystalline insoluble salts of polybasic metals-III: Preparation and ion exchange properties of cerium (IV) phosphate of various crystallinities. Journal of Inorganic and Nuclear (2012).

Chemistry 30, 295-304 (1968).

Albert, G. \& Costantino, U. Crystalline insoluble acid salts of tetravalent metals: X. Fibrous thorium phophate, a new inorganic ion-exchange material suitable for making (support-free) inorganic sheets. Journal of Chromatography A 50, 482-486 (1970).

26 Shakshooki, S., El-Akari, F., El-Fituri, S. \& El-Fituri, S. in Advanced Materials Research. 3-8 (Trans Tech Publ).

27 Lee, J. W. et al. Synthesis and characterization of acid-doped polybenzimidazole membranes by sol-gel and post-membrane casting method. Journal of Membrane Science 357, 130-133 (2010).

28 Ma, Y.-L., Wainright, J., Litt, M. \& Savinell, R. Conductivity of PBI membranes for high-temperature polymer electrolyte fuel cells. Journal of the Electrochemical Society 151, A8 (2003).

29 Li, J. et al. High-Temperature Proton-Exchange-Membrane Fuel Cells Using an EtherContaining Polybenzimidazole Membrane as Electrolyte. ChemSusChem 5, 896-900 Lobato, J., Cañizares, P., Rodrigo, M. A., Úbeda, D. \& Pinar, F. J. Promising TiOSO4 

ChemSusChem 4, 1489-1497 (2011).

382

Li, X. et al. Highly conductive and mechanically stable imidazole-rich cross-linked networks for high-temperature proton exchange membrane fuel cells. Chemistry of Materials 32, 1182-1191 (2020).

32 Singh, B. et al. High temperature polymer electrolyte membrane fuel cells with Polybenzimidazole-Ce0. 9Gd0. 1P2O7 and polybenzimidazole-Ce0. 9Gd0. 1P2O7graphite oxide composite electrolytes. Journal of Power Sources 401, 149-157 (2018).

33 Sun, X. et al. Proton conductivity of $\mathrm{CeP} 2 \mathrm{O} 7$ for intermediate temperature fuel cells. Solid State Ionics 179, 1138-1141 (2008).

34 Chen, X. et al. A proton conductor electrolyte based on molten CsH5 (PO4) 2 for intermediate-temperature fuel cells. RSC advances 8, 5225-5232 (2018).

35 Jensen, A. H., Li, Q., Christensen, E. \& Bjerrum, N. J. Intermediate temperature fuel cell using CsH2PO4/ZrO2-based composite electrolytes. Journal of the Electrochemical Society 161, F72 (2013).

36 Nagao, M. et al. A proton-conducting In3+-doped SnP2O7 electrolyte for intermediatetemperature fuel cells. Electrochemical and Solid State Letters 9, A105 (2006).

37 Uda, T. \& Haile, S. M. Thin-membrane solid-acid fuel cell. Electrochemical and Solid State Letters 8, A245 (2005).

38 Duan, C. et al. Readily processed protonic ceramic fuel cells with high performance at low temperatures. Science 349, 1321-1326 (2015).

39 Hibino, T. et al. A low-operating-temperature solid oxide fuel cell in hydrocarbon-air mixtures. Science 288, 2031-2033 (2000).

40 Seo, K., Nam, K.-H. \& Han, H. proton transport in Aluminum-Substituted Mesoporous 
Silica channel-embedded High-temperature Anhydrous proton-exchange Membrane fuel cells. Scientific reports 10, 1-9 (2020).

406

407

408

409

410

411

412

413

414

415

416

417

418

419

420

421

422

423

424

425

426

427

41 Li, Y. et al. Recent advances in the fabrication of advanced composite membranes. Journal of Materials Chemistry A 1, 10058-10077 (2013).

42 Jensen, J. O., Li, Q., He, R., Pan, C. \& Bjerrum, N. 100-200 C polymer fuel cells for use with NaAlH4. Journal of alloys and compounds 404, 653-656 (2005).

43 Mustarelli, P., Quartarone, E., Grandi, S., Carollo, A. \& Magistris, A. Polybenzimidazole-Based Membranes as a Real Alternative to Nafion for Fuel Cells Operating at Low Temperature. Advanced Materials 20, 1339-1343 (2008).

44 Bhavsar, R. S., Kumbharkar, S. C., Rewar, A. S. \& Kharul, U. K. Polybenzimidazole based film forming polymeric ionic liquids: synthesis and effects of cation-anion variation on their physical properties. Polymer Chemistry 5, 4083-4096 (2014).

45 Zhao, L. et al. Imidazole-doped cellulose as membrane for fuel cells: structural and dynamic insights from solid-state NMR. The Journal of Physical Chemistry C 120, 19574-19585 (2016).

46 Goward, G. R., Schuster, M. F., Sebastiani, D., Schnell, I. \& Spiess, H. W. Highresolution solid-state NMR studies of imidazole-based proton conductors: Structure motifs and chemical exchange from 1H NMR. The Journal of Physical Chemistry B 106, 9322-9334 (2002).

47 Zhang, J. et al. PEM fuel cells operated at $0 \%$ relative humidity in the temperature range of 23-120 C. Electrochimica Acta 52, 5095-5101 (2007).

48 Mamlouk, M. \& Scott, K. The effect of electrode parameters on performance of a phosphoric acid-doped PBI membrane fuel cell. International journal of hydrogen energy 35, 784-793 (2010). 
42849 Staffell, I. et al. The role of hydrogen and fuel cells in the global energy system. Energy \& Environmental Science 12, 463-491 (2019).

430

431 
a
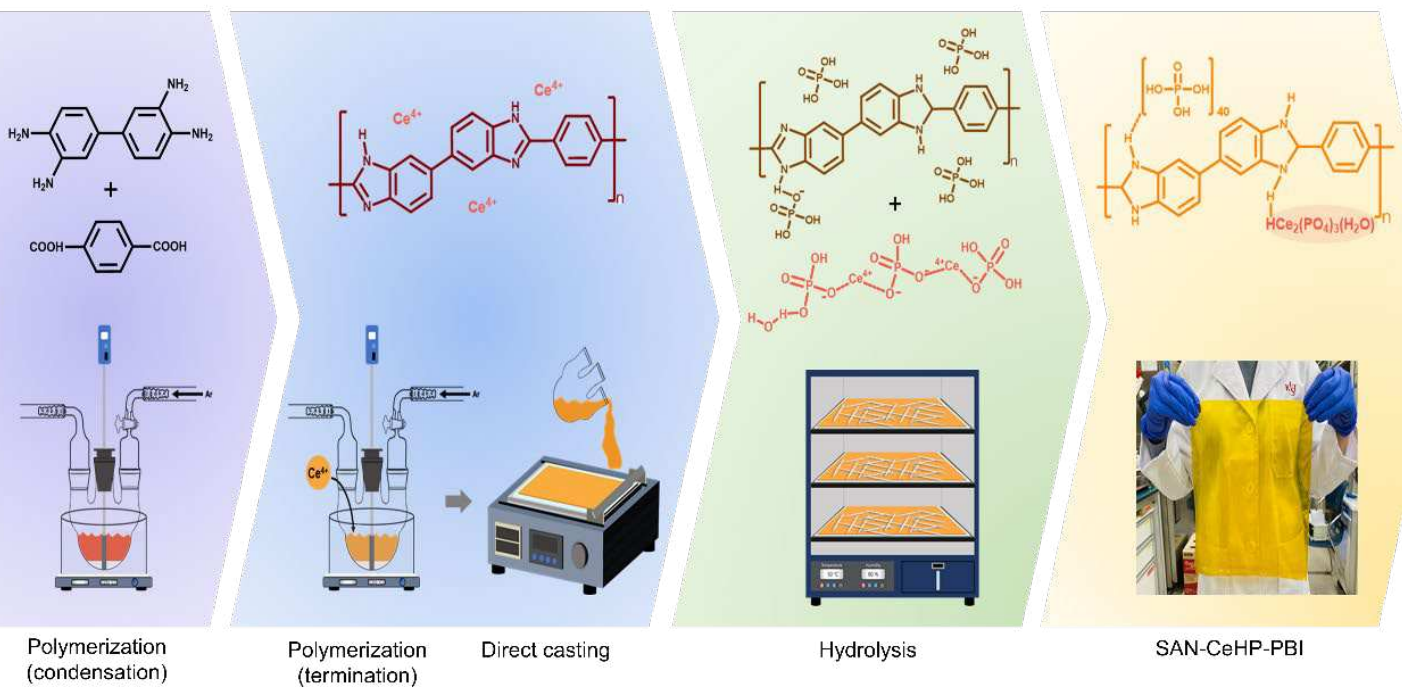

Hydrolysis

SAN-CeHP-PBI

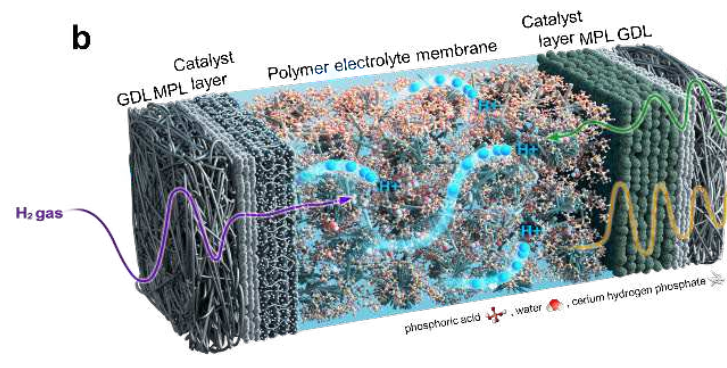

d

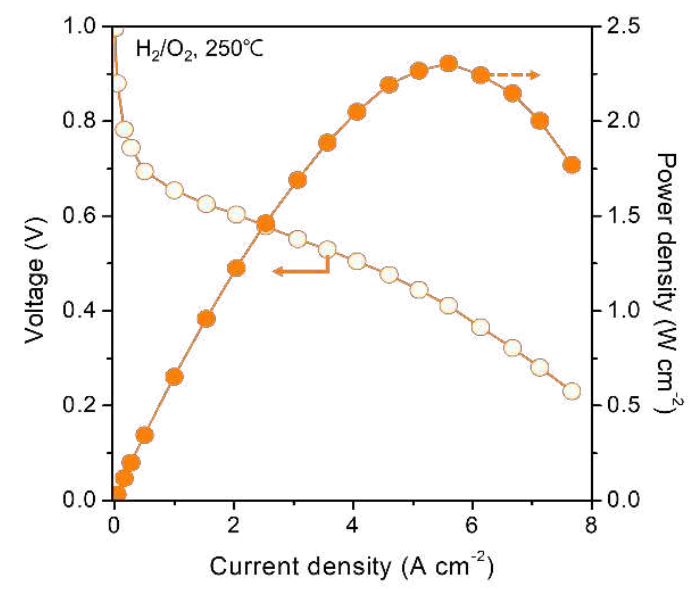

e

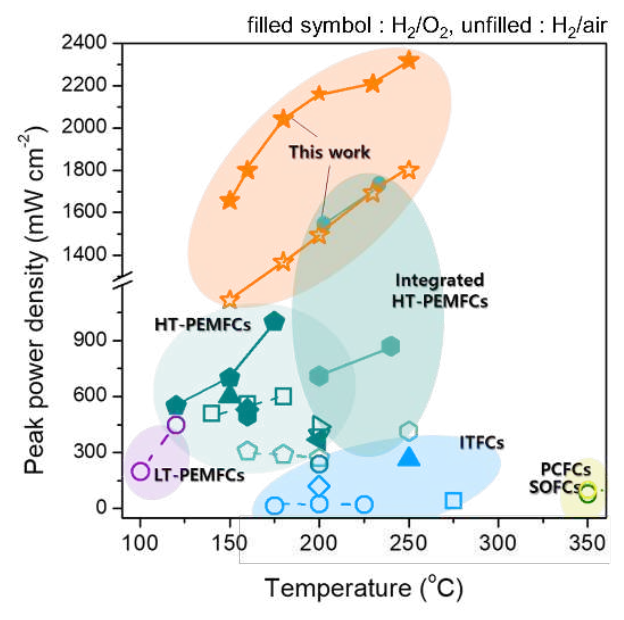

e

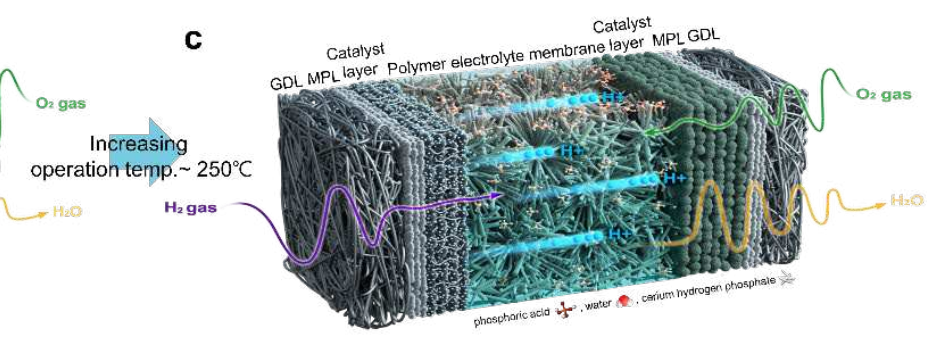

433 Figure 1 I Self-assembled network polymer electrolyte membrane

434 a, The formation of self-assembled network polymer electrolyte membrane; Chemical structure of SAN-CeHP-PBI membrane and schematic diagram of the in-situ sol-gel process. $(30 \mathrm{~cm} \times$ 
$43630 \mathrm{~cm}, 110 \mu \mathrm{m})$. b,c, Scheme for the operating principle of PA doped SAN-CeHP-PBI

437 composite membranes; formation of cerium hydrogen phosphate proton pathway structures and

438 its role in the stabilization of proton conduction (c) at below $180^{\circ} \mathrm{C}$ and (d) at elevated high

439 temperature of over $200{ }^{\circ} \mathrm{C}$. d, $\mathrm{H}_{2} / \mathrm{O}_{2}$ fuel cell performance, $i$-V curve with $\mathrm{Pt} / \mathrm{C}\left(1.5 \mathrm{mg}_{\mathrm{Pt}}{ }^{\circ} \mathrm{cm}^{-}\right.$

$\left.440{ }^{2}\right)$ and the PA doped SAN-CeHP-PBI composite membrane $(t=110 \mu \mathrm{m})$ at $250{ }^{\circ} \mathrm{C}$ under 3 bar

441 without humidification. e, Performance comparison of different types of fuel cells; filled

442 symbol: $\mathrm{H}_{2} / \mathrm{O}_{2}$; unfilled: $\mathrm{H}_{2}$ /Air.

443

444

445

446

447

448

449

450

451

452

453

454

455

456

457 
a

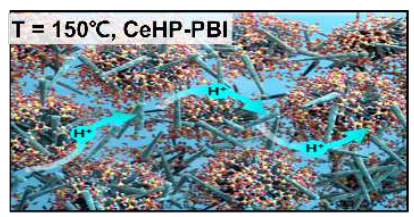

C

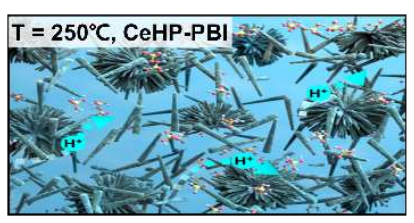

b

d
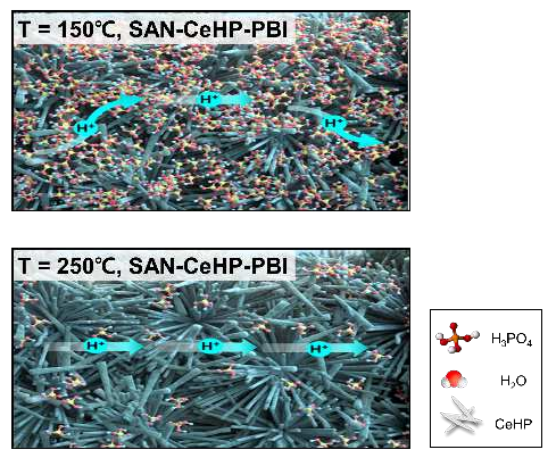

g

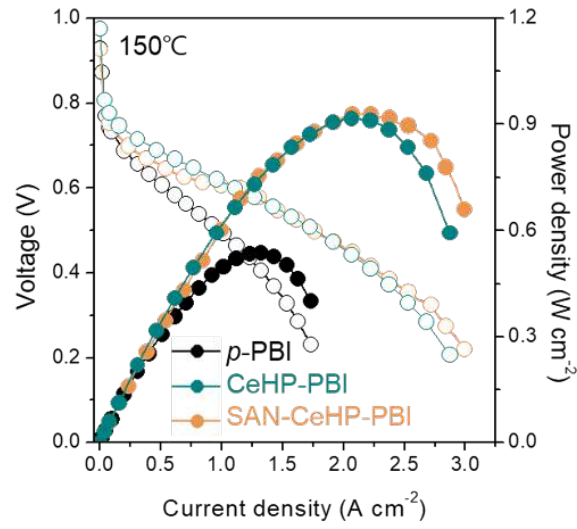

i

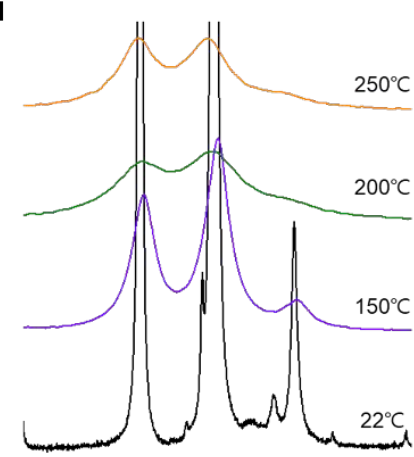

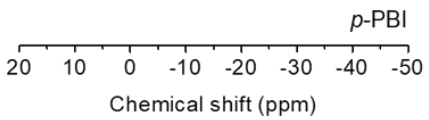

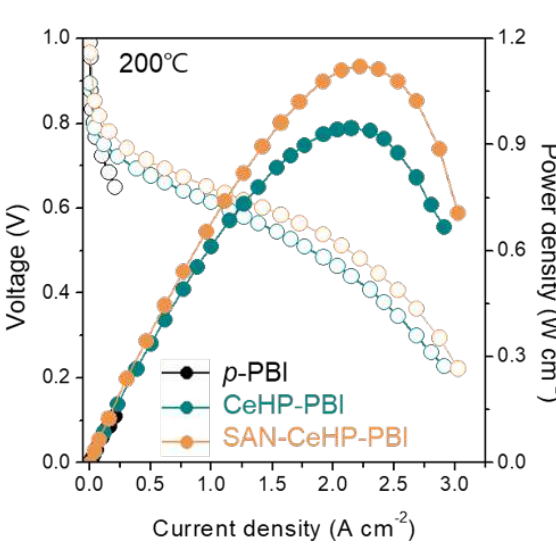

j
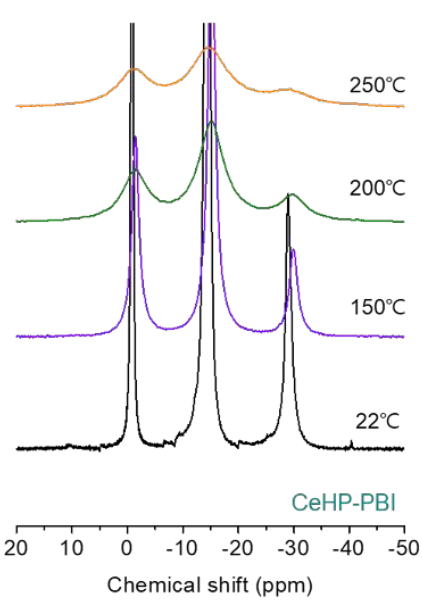

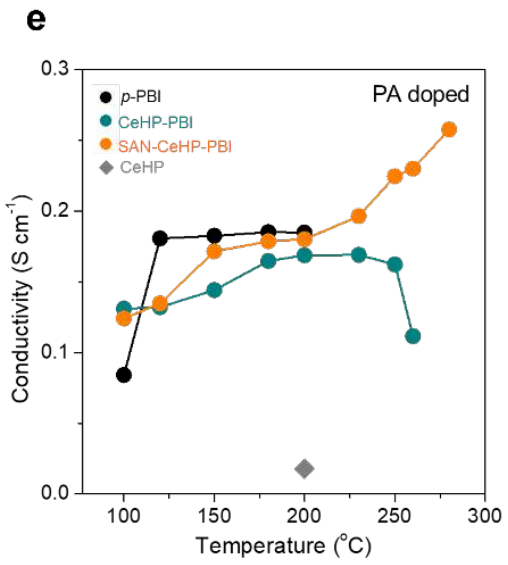

h

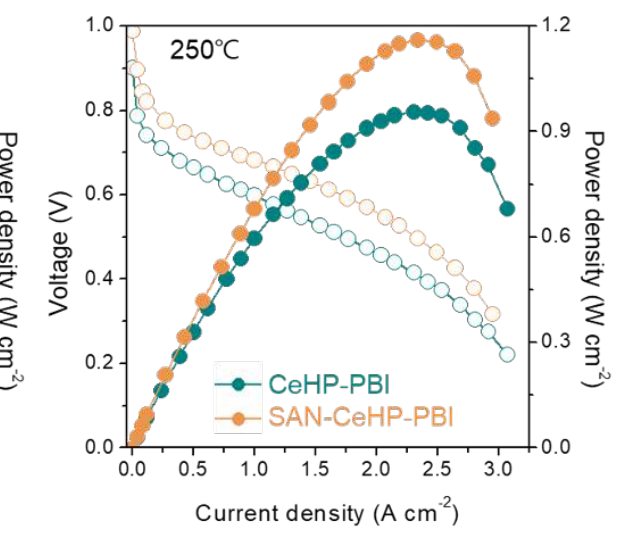

k
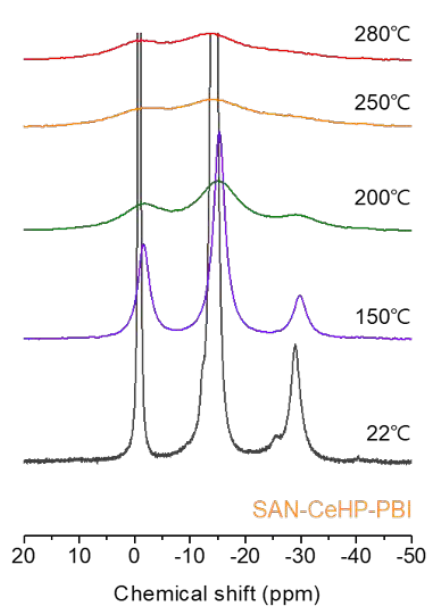

459 Figure 2 | Role of self-assembled network

460 a-d, Scheme of proton conducting path in composite membrane: CeHP-PBI composite

461 membrane at (a) $150^{\circ} \mathrm{C}$ and (b) $250^{\circ} \mathrm{C}$ in comparison with SAN-CeHP-PBI composite 
membrane at (c) $150^{\circ} \mathrm{C}$ and (d) $250^{\circ} \mathrm{C}$; formation of cerium hydrogen phosphate nanofibrous

463 structure during polymerization to form the attached and stabilized self-assembled network

464 channels anchored in PBI. e, Through-plane proton conductivity of SAN-CeHP-PBI composite

465 membranes in comparison with $p$-PBI membrane, CeHP-PBI composite membrane, and

466 Cerium hydrogen phosphate sheet under dry conditions as a function of temperature. $\mathbf{f}-\mathbf{h}$,

$467 \mathrm{H}_{2} /$ Air fuel cell performance, with $\mathrm{Pt} / \mathrm{C}\left(2.0 \mathrm{mg}_{\mathrm{Pt}} \cdot \mathrm{cm}^{-2}\right.$, BASF commercial electrode $)$ and the

468 (f) $p$-PBI membrane $(t=110 \mu \mathrm{m}),(\mathrm{g})$ CeHP-PBI composite membrane $(t=110 \mu \mathrm{m})$ and $(\mathrm{h})$

469 SAN-CeHP-PBI composite membrane $(t=110 \mu \mathrm{m})$ with no backpressure at $150-250{ }^{\circ} \mathrm{C} . \mathbf{i}-\mathbf{k}$,

$470 \quad{ }^{31} \mathrm{P}$ solid-state MAS NMR spectra of (i) $p$-PBI membrane, (j) CeHP-PBI composite membrane,

471 and (k) SAN-CeHP-PBI composite membrane shown for all three samples as T rises.

472

473

474

475

476

477

478

479

480

481 
a

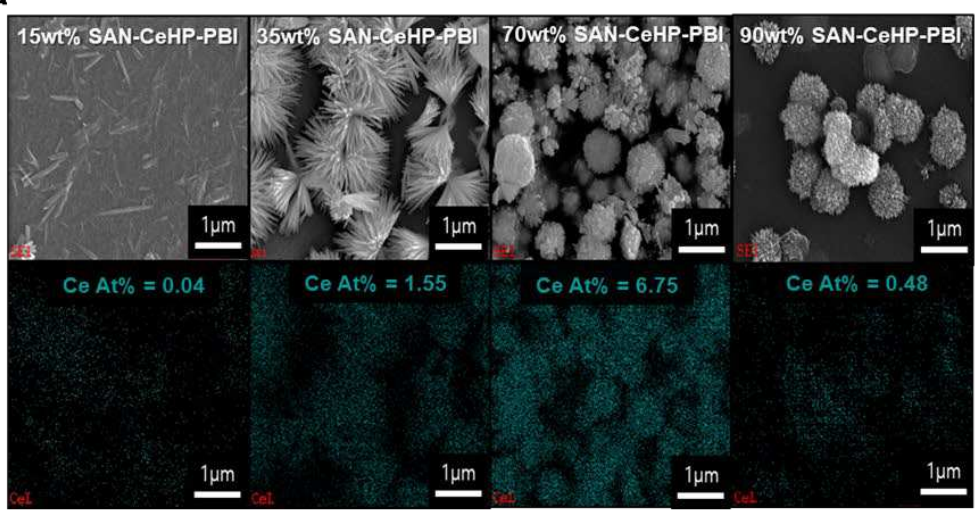

C

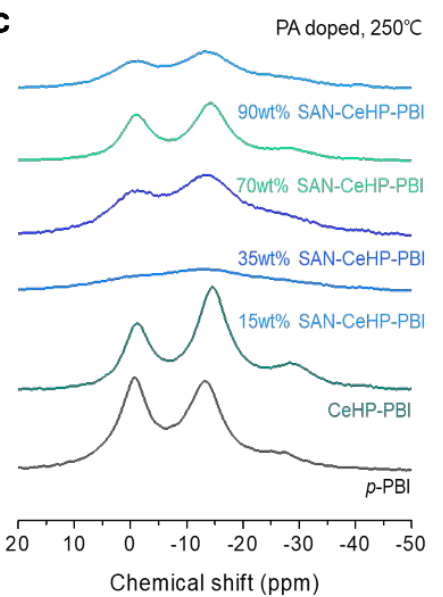

d

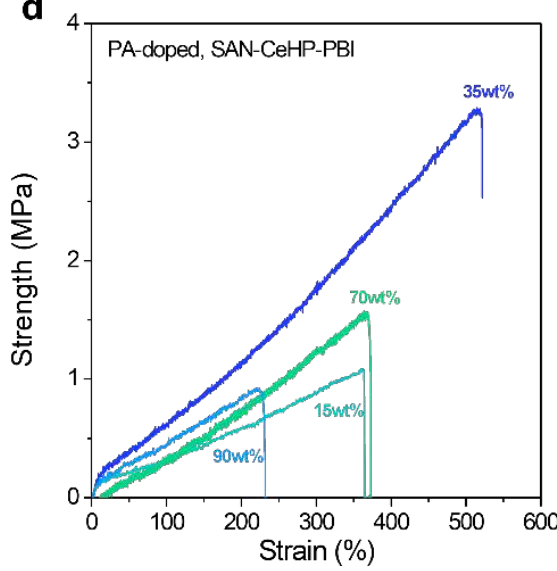

$100 \% \mathrm{H}_{2}$

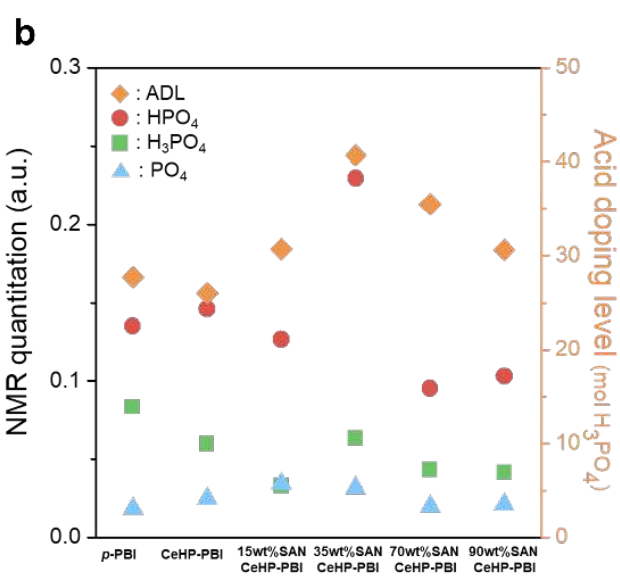

e

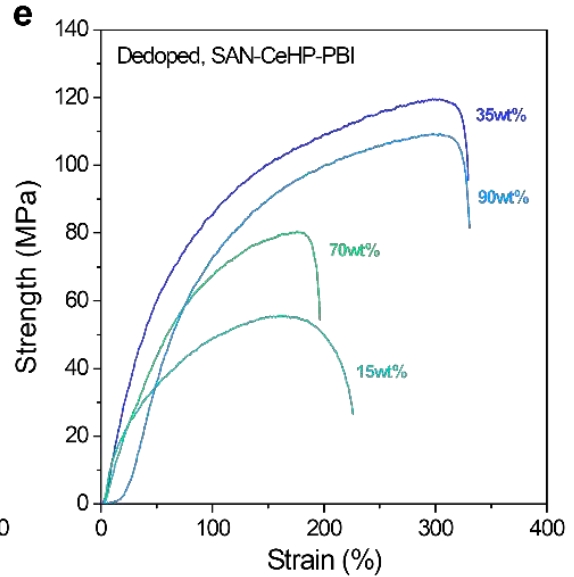

$90 \% \mathrm{H}_{2} \quad 10 \% \mathrm{CO}$
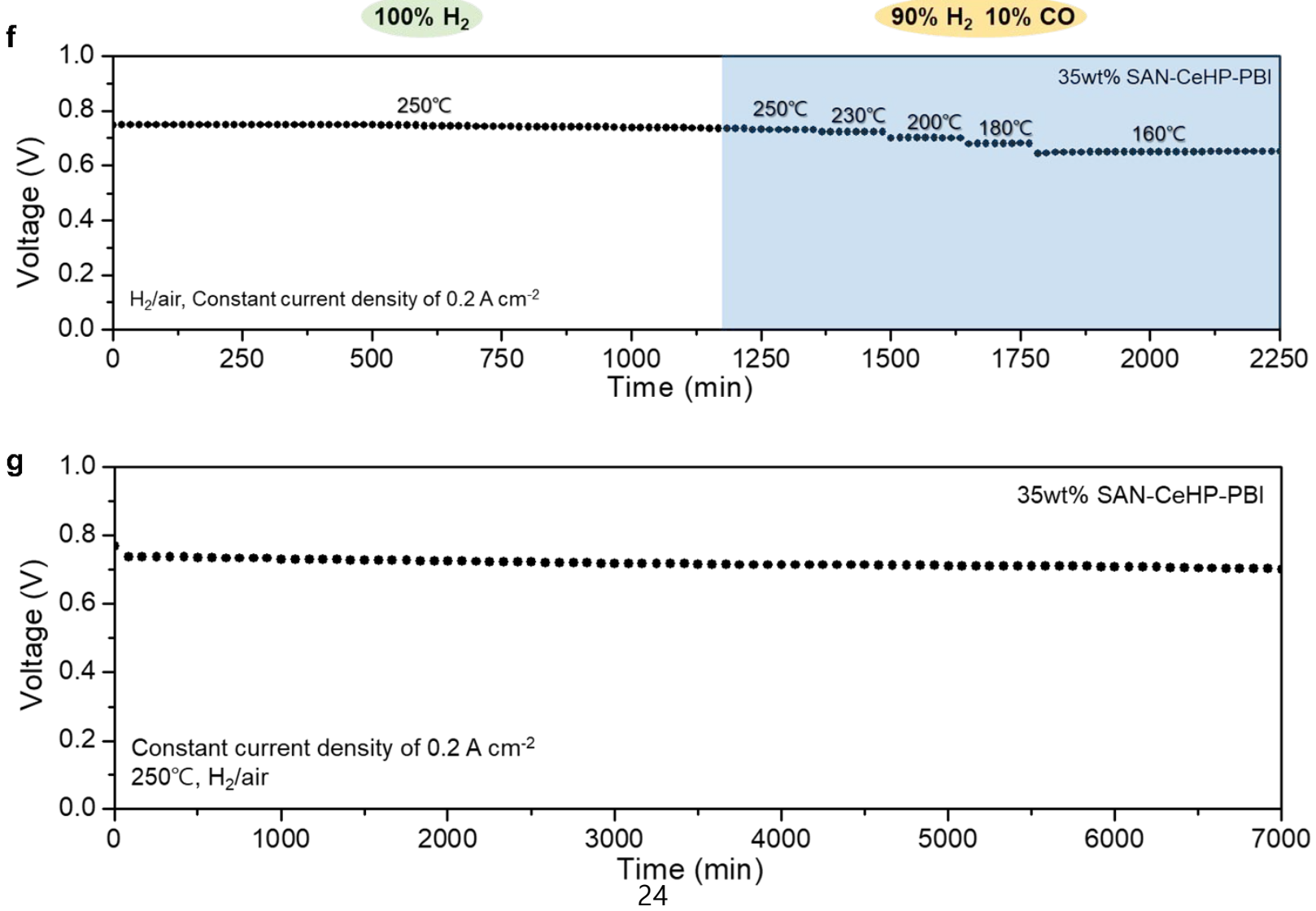
a, Scanning electron microscope images and EDX mapping images of Ce element; the various De-doped SAN-CeHP-PBI composite membranes with 15, 35, 70, and $90 \mathrm{wt} \%$ Cerium precursor. b, Acid doping level (mol $\mathrm{H}_{3} \mathrm{PO}_{4} /$ unit of $\mathrm{PBI}$ ) and $\mathrm{NMR}$ quantitation of ${ }^{31} \mathrm{P}$ signals 487 for $\mathrm{H}_{3} \mathrm{PO}_{4}, \mathrm{HPO}_{4}$, and $\mathrm{PO}_{4}$ phases normalized by the weight of all the samples: ADL, $\diamond \mathrm{H}_{3} \mathrm{PO}_{4}$, 488 $\square ; \mathrm{HPO}_{4},{ }^{\bullet} ; \mathrm{PO}_{4}, \triangle . \mathbf{c},{ }^{31} \mathrm{P}$ solid-state MAS NMR spectra of the various PA-doped SAN-CeHPPBI composite membranes with $15,35,70$ and $90 \mathrm{wt} \%$ Cerium precursor at $250^{\circ} \mathrm{C}$. d-e, Tensile property comparison of the membrane with various cerium contents (d) PA-doped and (e) Dedoped SAN-CeHP-PBI composite membranes with 15, 35, 70, and $90 \mathrm{wt} \%$ Cerium precursor f, Fuel cell performance under the flow of $\mathrm{H}_{2}$ containing $10 \% \mathrm{CO}$ versus air at different temperatures. The $\mathrm{Pt} / \mathrm{C}$ electrodes $\left(1.5 \mathrm{mg}_{\mathrm{Pt}} \mathrm{cm}^{-2}\right)$ and $35 \mathrm{wt} \%$ SAN-CeHP-PBI composite membrane $(t=110 \mu \mathrm{m})$ were used. g, Long-term stability of the fuel cell with $35 \mathrm{wt} \% \mathrm{SAN}$ CeHP-PBI composite membrane $(t=110 \mu \mathrm{m})$ at a constant current density of $0.2 \mathrm{~A} \cdot \mathrm{cm}^{-2}$ and $250{ }^{\circ} \mathrm{C}$ under $\mathrm{H}_{2} /$ air flow without humidification. The fuel cell was prepared with $\mathrm{Pt} / \mathrm{C}$ 497 electrode $\left(1.5 \mathrm{mgt}_{\mathrm{Pt}} \cdot \mathrm{cm}^{-2}\right)$. 
a

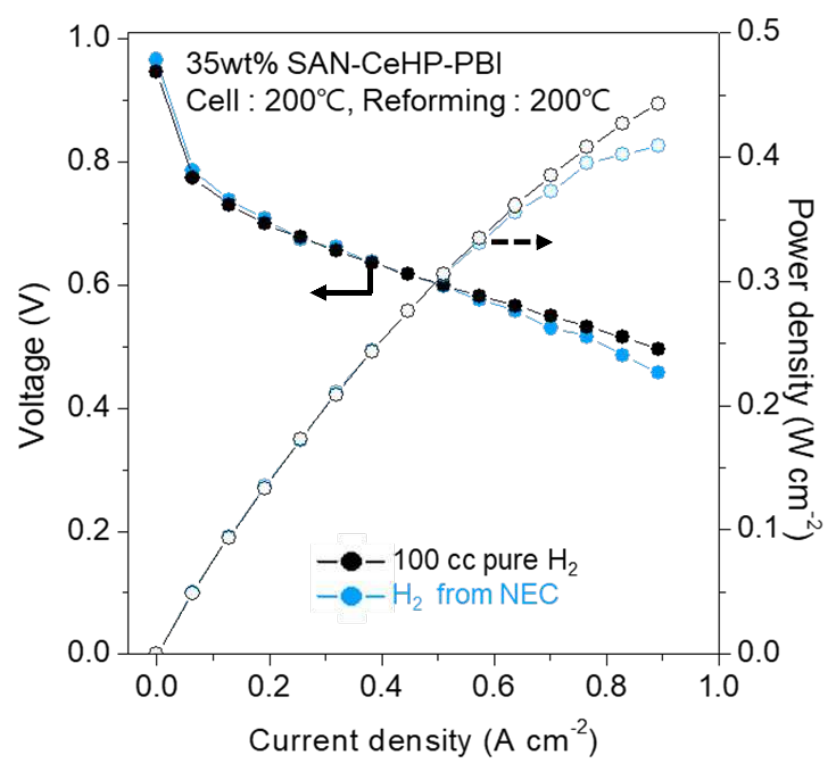

C

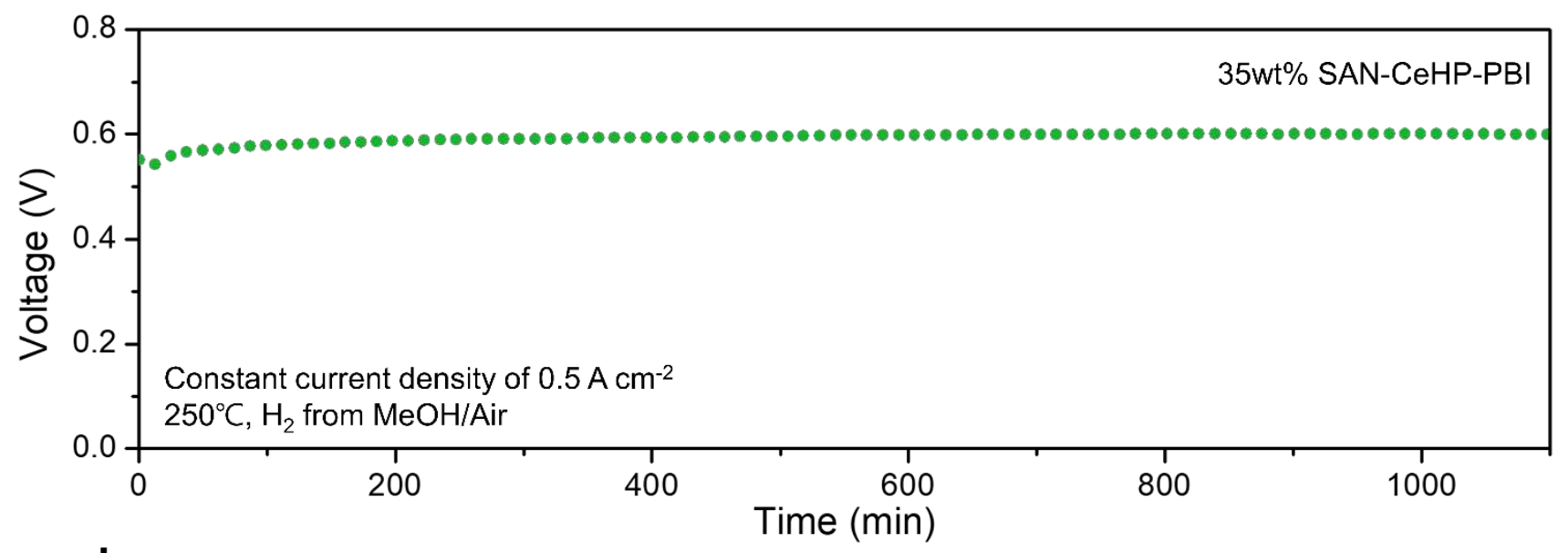

d
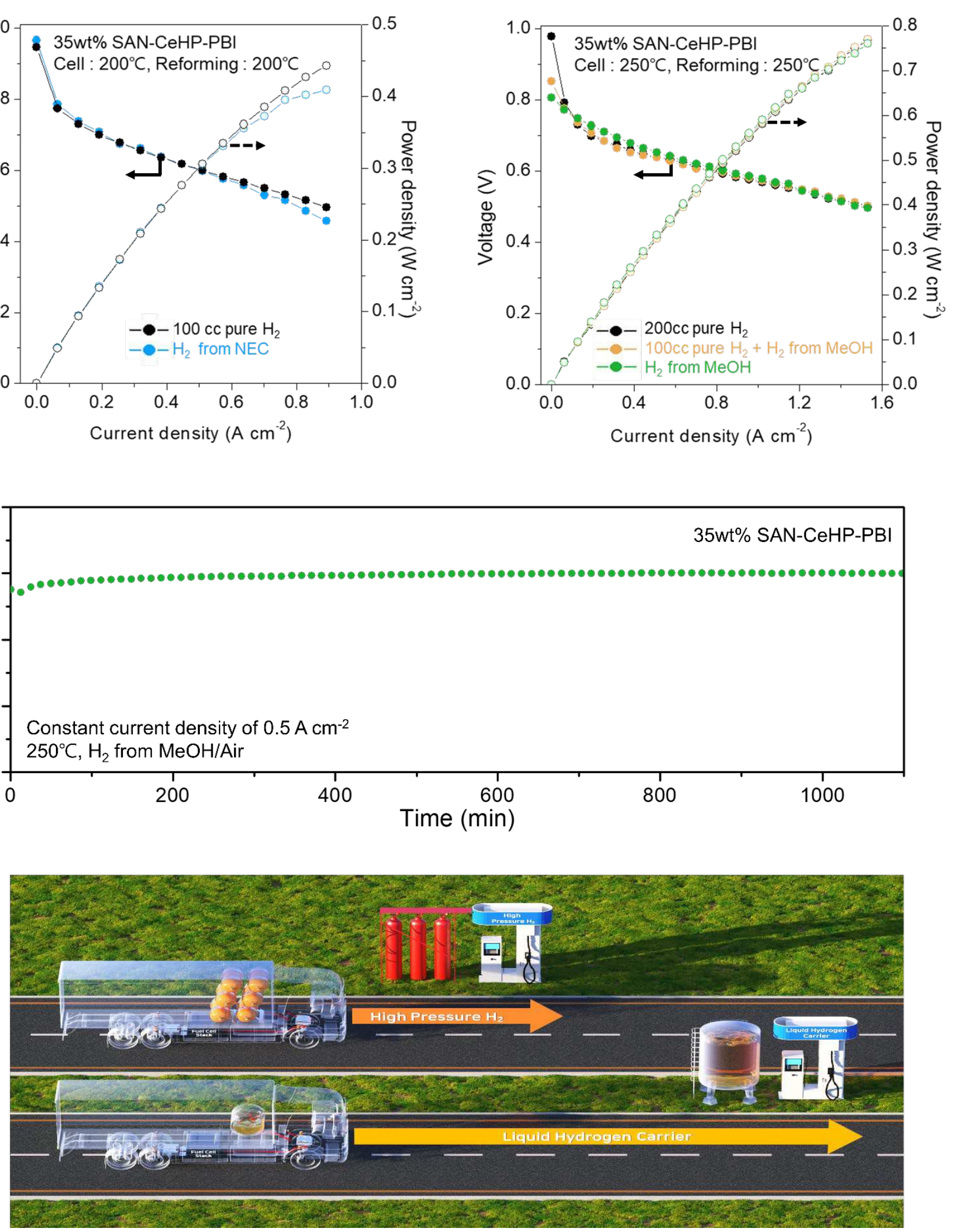
a, $i$-V curve of the single cell with Pt/C electrodes $\left(1.5 \mathrm{mgt}_{\mathrm{Pt}} \mathrm{cm}^{-2}\right)$ and PA-doped $35 \mathrm{wt} \% \mathrm{SAN}-$ CeHP-PBI composite membrane using fuel with $100 \mathrm{sccm}$ pure $\mathrm{H}_{2}$ and $100 \mathrm{sccm} \mathrm{H}_{2}$ from the dehydrogenation of hydrogenated N-ethylcarbazole. Both the fuel cell and the dehydrogenation unit attached directly to the fuel cell were maintained at $200^{\circ} \mathrm{C} . \mathbf{b}, i-\mathrm{V}$ curve of the single-cell with $\mathrm{Pt} / \mathrm{C}$ electrodes $\left(1.5 \mathrm{mg}_{\mathrm{Pt}} \mathrm{cm}^{-2}\right)$ and PA-doped $35 \mathrm{wt} \%$ SAN-CeHP-PBI composite membrane using $200 \mathrm{sccm}$ pure $\mathrm{H}_{2}, 100 \mathrm{sccm}$ pure $\mathrm{H}_{2}+100 \mathrm{sccm} \mathrm{H}_{2}$-rich gas from methanol reforming, and $200 \mathrm{sccm}_{2}$-rich gas from methanol reforming. Both the fuel cell and the reforming unit attached directly to the fuel cell were maintained at $250{ }^{\circ} \mathrm{C}$, and the $\mathrm{CO}$ content in the H2-rich gas before entering the fuel cell was 1-3 vol\%. c, Long-term stability of the fuel cell with PA-doped $35 \mathrm{wt} \%$ SAN-CeHP-PBI composite membrane $(t=110 \mu \mathrm{m})$ using Pt/C electrodes $\left(1.5 \mathrm{mgt}_{\mathrm{Pt}} \mathrm{cm}^{-2}\right)$. The fuel cells were tested at a constant current density of $0.5 \mathrm{~A} \cdot \mathrm{cm}^{-}$ ${ }^{2}$ and $250{ }^{\circ} \mathrm{C}$ using $\mathrm{H}_{2}$-rich gas and air under anhydrous conditions, and the $\mathrm{CO}$ content in the H2-rich gas before entering the fuel cell was 1-3 vol\%. d, Schematic diagram of integrated system application; Extended long-range heavy-duty trucks powered with HT-PEMFC stacks to which $\mathrm{H}_{2}$ is supplied from $\mathrm{H}_{2}$ gas tanks or by LHCs. 
Materials. 3,3'-Diaminobenzidine (DAB, Alfa Aesar) and terephthalic acid (TPA, SigmaAldrich) were dried at $60{ }^{\circ} \mathrm{C}$ for one day under a vacuum. Cerium (IV) sulphate tetrahydrate, PPA (115\% phosphoric acid equivalent, Sigma-Aldrich), PA solution ( $85 \mathrm{wt} \%$ in $\mathrm{H}_{2} \mathrm{O}$, SigmaAldrich), and sulfuric acid (99.9\%, Sigma-Aldrich) were purchased and used as received. Pt/C catalyst (46.2 wt\%, TANAKA, Japan), gas diffusion electrodes (GDEs, 38BC, SGL), and polytetrafluoroethylene ( $60 \mathrm{wt} \%$ dispersion in $\mathrm{H}_{2} \mathrm{O}$, Sigma-Aldrich) were used to fabricate the anodes. BASF commercial electrodes: $\mathrm{Pt} / \mathrm{C}\left(\mathrm{Pt}\right.$ loading: $\left.1.0 \mathrm{mg}_{\mathrm{Pt}} \cdot \mathrm{cm}^{-2}\right)$ were used as anodes, and Pt-alloy/C (Pt loading: $\left.1.0 \mathrm{mg}_{\mathrm{Pt}} \cdot \mathrm{cm}^{-2}\right)$ were used as cathodes.

Synthesis of cerium (IV) hydrogen phosphates $\left(\mathrm{HCe}_{2}\left(\mathrm{PO}_{4}\right)_{3}\left(\mathrm{H}_{2} \mathrm{O}\right)\right)$. Cerium(IV) hydrogen phosphate was synthesized as described in a previous $\operatorname{paper}^{26}$. Cerium(IV) sulphate tetrahydrate (2.02 g) was dissolved in $100 \mathrm{~mL}$ of $0.5 \mathrm{M} \mathrm{H}_{2} \mathrm{SO}_{4}$. Then, $100 \mathrm{~mL}$ of $6 \mathrm{M} \mathrm{H}_{3} \mathrm{PO}_{4}$ was added dropwise to the solution under stirring at $80{ }^{\circ} \mathrm{C}$. After complete addition, the mixture was allowed to digest at this temperature for $4 \mathrm{~h}$. Subsequently, $1 \mathrm{~L}$ of distilled water $\left(\sim 60{ }^{\circ} \mathrm{C}\right)$ was added with stirring for $1 \mathrm{~h}$. The yellow product was washed several times with distilled water, filtered, and dried at $50{ }^{\circ} \mathrm{C}$ for $24 \mathrm{~h}$ in a convection oven.

Synthesis of SAN-CeHP-PBI polymer and membrane fabrication. An in-situ sol-gel process was employed to fabricate the SAN-CeHP-PBI polymer membranes ${ }^{27}$. DAB (3.0 g, $\left.0.014 \mathrm{~mol}\right)$, TPA (2.3 g, $0.014 \mathrm{~mol})$, and PPA (125 g) were mixed in a round-bottom flask and stirred using a mechanical overhead stirrer for $15 \mathrm{~h}$ at $150{ }^{\circ} \mathrm{C}$ under argon atmosphere. The reaction temperature was then increased to $220{ }^{\circ} \mathrm{C}$, and the mixture was maintained at this temperature 
545 for $1 \mathrm{~h}$. During polymerization, the reaction mixture became viscous and turned dark brown.

546 Then, $25 \mathrm{~mL}$ of PA solution was poured into the reaction mixture to terminate the reaction.

547 Finally, cerium(IV) sulphate tetrahydrate (by mass ratio to the polymer monomer) was added,

548 and the mixture was stirred for $2 \mathrm{~h}$. Upon completion of the reaction, the polymerization solution

549 was applied to a glass plate, and the electrolyte membrane with a uniform thickness was prepared

550 by the doctor blade method. The electrolyte membrane was then placed in a temperature and

551 humidity-controlled chamber (at $50{ }^{\circ} \mathrm{C}$ and $50 \%$ humidity) for one day to obtain PA-doped

SAN-CeHP-PBI for MEA fabrication.

553

Synthesis of CeHP-PBI and pristine $p$-PBI polymer and membrane fabrication. This

synthesis is almost the same as the SAN-CeHP-PBI membrane fabrication described above.

However, CeHP was added instead of the Ce precursor during the termination process. In the pristine $p$-PBI, the reaction was terminated by adding PA at the end of the reaction without adding any other additive.

559

Proton conductivity measurement. The ionic conductivity of the membrane samples with dimensions of $1 \mathrm{~cm} \times 4 \mathrm{~cm}$ was measured by four-point-probe-based alternating current impedance spectroscopy in the frequency range of $50 \mathrm{kHz}$ to $1 \mathrm{MHz}$ using a Bio-Logic SAS instrument with EC-lab software (Knoxville, TN, USA). The temperature was controlled by a fuel cell station (CNL, Seoul, Korea) under nitrogen flow. The relative humidity of the conductivity cell was maintained at $0 \%$. The through-plane conductivity of all the membrane samples was measured, and the proton conductivity $(\sigma)$ was calculated from the following equation: 


$$
\sigma=\frac{L}{R S}
$$

569

570

571

572

573

574

575

576

577

578

579

580

581

582

583

584

585

586

587

588

where $\mathrm{L}$ is the distance between the counter electrode and working electrode, $\mathrm{R}$ is the impedance of the membrane, and $\mathrm{S}$ is the cross-sectional surface area of the membrane samples $\left(\mathrm{cm}^{2}\right)$.

Structure and morphology characterization. Field-emission scanning electron microscopy and EDX mapping (Teneo VS, FEI, USA) were performed to analyze the surface and crosssections of the PA-doped and de-doped membrane samples and CeHP sheets. X-ray diffractometer (D8 ADVANCE, LynxEye) patterns of the samples were obtained using monochromic $\mathrm{CuK} \alpha$ radiation obtained at $40 \mathrm{kV}$ and $200 \mathrm{~mA}$ with a scan rate of $1 \mathrm{~s}$ per step $\left(0.05^{\circ}\right)$

Mechanical properties. The mechanical properties of the prepared membranes were tested using a universal testing machine (UTM, AGS-J 500 N, Shimadzu, Kyoto, Japan) at a stretching rate of $10 \mathrm{~mm} / \mathrm{min}$. TGA was performed using a Q50 apparatus (TA Instruments). The thermal stabilities of the PBI membranes and the CeHP sheet were examined via TGA (Q500 Thermobalance, TA Instruments, USA). Under ambient conditions, $10 \mathrm{mg}$ of the PBI membranes and the CeHP sheet were heated at a rate of $10{ }^{\circ} \mathrm{C} / \mathrm{min}$ to $800^{\circ} \mathrm{C}$

In-situ high-temperature Raman spectroscopy. Raman measurements were performed with a Renishaw inVia Raman microscope. The Raman microscope was equipped with a red laser diode, for which $\lambda=785 \mathrm{~nm}$ and output power $=50 \mathrm{~mW}$. The laser power was optimized to avoid any photobleaching or damages to the membranes by the excitation energy. The samples were kept in a dry chamber during data acquisition to prevent any interaction between the air humidity and 
589 the phosphoric acid. Spectra were collected in the range of $700-2000 \mathrm{~cm}^{-1}$, and the spectral 590 resolution was $9 \mathrm{~cm}^{-1}$.

High-temperature solid-state NMR spectroscopy. ${ }^{1} \mathrm{H}$ and ${ }^{31} \mathrm{P}$ MAS NMR spectroscopy was

592 performed using a Bruker DSX-500 spectrometer and a 4 mm Bruker MAS NMR probe. First, 593 the PEM was loaded into a $4 \mathrm{~mm}$ rotor, which was evacuated at $130{ }^{\circ} \mathrm{C}$ for $1 \mathrm{~h}$. Then, it was purged with Ar gas and closed with a tight-fitting Vespel cap for MAS at room temperature or a variable temperature for in-situ NMR measurements. The samples were spun at $8 \mathrm{kHz}$ under a dry $\mathrm{N}_{2}$ atmosphere. All spectra were reported in ppm using TMS and $\mathrm{H}_{3} \mathrm{PO}_{4}$ as standard references for $1 \mathrm{H}$ and ${ }^{31} \mathrm{P}$ NMR spectroscopy, respectively, calibrated at $0 \mathrm{ppm}$.

Acid doping levels measurement. The PA-doping level of PEMs was determined by the weight analysis method through the following procedure. PEM samples measuring $3.8 \mathrm{~cm} \times 3.8 \mathrm{~cm}$ were weighed, the water content of PEM samples were measured using moisture analyzers (MA.R series, RADWAG); the samples were immersed in water for 3 days and dried in a vacuum plate at $130{ }^{\circ} \mathrm{C}$ for $8 \mathrm{~h}$ and weighed again. The doping level was calculated from the following equation:

$$
\text { Doping level }=\frac{P A \text { mole }}{P B I P R U \text { mole }}=\frac{W_{P A} / M_{P A}}{W_{\text {polymer }} / M_{\text {polymer }}}
$$

where $\mathrm{W}_{\mathrm{PA}}(\mathrm{g})$ is the PA weight in the polymer, $\mathrm{M}_{\mathrm{PA}}\left(\mathrm{g} \mathrm{mol}^{-1}\right)$ is the molecular weight of the PA 605 in the polymer, $\mathrm{W}_{\text {polymer }}(\mathrm{g})$ is the dry polymer weight, and $\mathrm{M}_{\text {polymer }}\left(\mathrm{g} \mathrm{mol}^{-1}\right)$ is the molecular 606 weight of the polymer repeat unit.

The weight of PA ( $\left.\mathrm{W}_{\mathrm{PA}}\right)$ was calculated from the following equation:

$$
W_{P A}=W_{\text {polymer }+P A}-W_{\text {polymer }}
$$


where $\mathrm{W}_{\mathrm{PBI}+\mathrm{PA}}(\mathrm{g})$ is the weight of the polymer from which moisture has been removed.

610

611

612

613

614

615

616

617

618

619

620

621

622

623

624

625

626

627

628

629

630

MEA fabrication. MEAs were prepared from catalyst inks containing Pt/C catalysts (TANAKA, Pt 46.2 wt.\%) and a PTFE solution (Sigma Aldrich, 60 wt.\% dispersion in $\mathrm{H}_{2} \mathrm{O}$ ) as the binder, in addition to isopropyl alcohol (IPA) and deionized water (DIW). The catalyst ink composition was $4.3 \mathrm{wt} \% \mathrm{Pt} / \mathrm{C}, 2.3 \mathrm{wt} \%$ PTFE solution, $66 \mathrm{wt} \%$ IPA, and $26 \mathrm{wt} \%$ DIW. The catalyst slurry was then auto-spray coated onto the gas diffusion layer (38BC, SGL). Subsequently, heat treatment was performed at $350{ }^{\circ} \mathrm{C}$ for 5 min under an argon environment. The catalyst-coated GDLs (Pt $1.5 \mathrm{mg} \mathrm{cm}^{-2}$ ) were used as anodes, and BASF commercial electrodes (Pt $1.0 \mathrm{mg} \mathrm{cm}^{-2}$ ) were used as cathodes. In the experiment, to see the effect of the membrane, a BASF commercial electrode (Pt $1.0 \mathrm{mg} \mathrm{cm}^{-2}$ ) was used for the anode. Prior to assembly, the PEMs were heated at $130{ }^{\circ} \mathrm{C}$ for 15 minutes. The MEAs were assembled in the single-cell by placing the PA-doped PBI membrane between the anode and the cathode using gaskets. Hot pressing of the MEA was not carried out. The active area of each MEA was $7.84 \mathrm{~cm}^{2}$.

Fuel cell characterization. $\mathrm{H}_{2} / \mathrm{O}_{2}$ (or air) fuel cell performance of the MEAs was measured using a fuel cell test station (CNL, Seoul, Korea). The polarization curves of the MEAs were obtained at temperatures ranging from 150 to $250{ }^{\circ} \mathrm{C} . \mathrm{H}_{2}$ and $\mathrm{O}_{2}$ (or air) were supplied at a rate of 400 and 800 (or 1200) sccm, respectively. The same conditions were used for electrochemical impedance spectroscopy (EIS), performed at an amplitude of $10 \mathrm{~mA}$ and frequencies of $10 \mathrm{kHz}$ to $1 \mathrm{~Hz}$ in the cell voltage range of $0.85-0.6 \mathrm{~V}$. For long-term stability tests, the voltage at a constant current density $\left(0.2 \mathrm{~A} \cdot \mathrm{cm}^{-2}\right.$ or $\left.0.5 \mathrm{~A} \cdot \mathrm{cm}^{-2}\right)$ was measured every minute. The CO tolerance test was performed using $25 \mathrm{~cm}^{2}$ fuel cell hardware by feeding $10 \mathrm{wt} \% \mathrm{CO}$ in the $\mathrm{H}_{2}$ stream. The voltage at a constant current density of $0.2 \mathrm{~A} \cdot \mathrm{cm}^{-2}$ was measured at $250{ }^{\circ} \mathrm{C}$ as a function of time. 
Fuel cell operation with LHC dehydrogenation. To prepare a $\mathrm{H}_{2}$-rich $\mathrm{LHC}(\mathrm{LHC}+)$,

632

633

634

635

636

637

638

639

640

641

642

643

644

645

646

647

648

649

650

651

652

653

654

methanol (Samchun chemicals) was mixed with deionized water to obtain a S/C ratio of 1:1.

N-ethylcarbazole (NEC, Sigma Aldrich) was hydrogenated to perhydro N-ethylcarbazole (12NEC, Sigma Aldrich) for the dehydrogenation experiments. For the catalyst, commercial CuNi on alumina (MDC-3, Süd-Chemie) was used for methanol reforming, and Pd/C (Riogen) was used for NEC dehydrogenation. The flowrates of the gases, $\mathrm{N}_{2}$ for purging and $\mathrm{H}_{2}$ for catalyst reduction or the direct operation of PEMFCs, were controlled using electrical mass flow controllers (MFCs, F-201C, Bronkhorst, High-Tech). A high-pressure liquid chromatography pump (Series II Legacy HPLC pump, TELEDYNI SSI) was used to feed the methanol or 12-NEC into the reactor. The reactor was heated by electrical heaters with temperatures being controlled. After the reaction, the product gas was fed to the liquid-gas separator. The flowrates of the produced gas mixtures containing $\mathrm{H}_{2}$ were measured using film flow meters (SF-1U, Horiba, Japan). For power generation experiments, the performances of the fuel cell using $\mathrm{H}_{2}$ from a gas cylinder and that using $\mathrm{H}_{2}$ produced by the reactor were evaluated and compared. The product gas was fed either to the GC (Agilent 7890, Agilent) for compositional analysis or to the PEMFC for the power generation experiments.

\section{Data availability}

Data supporting the plots within this paper and other findings of this study are available from the corresponding author upon reasonable request.

Acknowledgements: This work was supported by the project "KIST Institutional Program" from the Korea Institute of Science and Technology and supported by the Industrial Strategic Technology Development Program (20011712) funded by the Ministry of Trade, Industry \& 
657 Author contributions: ${ }^{\dagger}$ These authors contributed equally to this work. S.Y. Lee and N.-W. 658 Nam developed the intellectual concept and supervised this research; H.-J. Kim guided the work; S. Lee., Y. Jo., and S.-J. Hwang, S. Y. Lee and N.-W. Nam wrote the manuscript. S. L., Y. J., and Y. K. designed all the experiments. S. Lee prepared the SAN-CeHP PBI polymer and performed the MEA fabrication and testing experiments of fuel cells. S. Lee measured all membrane properties and analyzed all experimental data. Y. Park prepared the dehydrogenation of hydrogenated N-ethylcarbazole. Y. Jo and Y. Kim measured the performance of HT-PEMFC integrated with $\mathrm{H}_{2}$ extraction unit. T. K. Lee conducted a Figure 1 schematic diagram. S. -J. Hwang conducted solid NMR analysis and analyzed NMR data. All the authors discussed the results and commented on the draft.

667

Competing interests: The authors declare no competing financial interests.

Supplementary Information is available for this paper.

Additional information: Correspondence and requests for materials should be addressed to S.

Y. L. (sylee5406@kist. re.kr), S. W. N. (swn@kist.re.kr) or H.-J. K. (hjkim25@kist.re.kr). Reprints and permissions information is available at www.nature.com/reprints

Extended Data Legends

Extended Data Figure 1 । Cerium hydrogen phosphate (CeHP). a, CeHP image. b, SEM 
679 image of CeHP surface. c, XRD profiles of CeHP at different temperatures: (a) initial product, 680 (b) heated at $130{ }^{\circ} \mathrm{C}$, and (c) heated at $300{ }^{\circ} \mathrm{C}$. d, Thermogravimetric analysis (TGA) profile

681

682

683

684

685

686

687

688

689

690

691

692

693

694

695

696

697

698

699

700

701

702 of CeHP.

\section{Extended Data Figure 2 | Solvation behavior of CeHP ionomer mixed with concentrated} $\mathbf{H}_{3} \mathbf{P O}_{4}$. a-d, Solid-state ${ }^{31} \mathrm{P}$ MAS NMR spectra of CeHP ionomer: (a) CeHP ionomer mixed with concentrated $\mathrm{H}_{3} \mathrm{PO}_{4}$, (b) after heating at $250{ }^{\circ} \mathrm{C}$, (c) mixed for different times, and (d) mixed at different temperatures.

Extended Data Figure 3 | Fuel cell test of SAN-CeHP-PBI. a-b, Scanning electron microscope images of PA-doped SAN-CeHP-PBI composite membrane after $100 \mathrm{~h}$ at (a) $150^{\circ} \mathrm{C}$ and (b) $250{ }^{\circ} \mathrm{C}$ of fuel cell testing. c-d, Fuel cell performance, $i-\mathrm{V}$ curve with $\mathrm{Pt} / \mathrm{C}\left(1.5 \mathrm{mg}_{\mathrm{Pt}}{ }^{*} \mathrm{~cm}^{-}\right.$ $\left.{ }^{2}\right)$ and the PA-doped SAN-CeHP-PBI composite membrane $(t=110 \mu \mathrm{m})$ using (c) $\mathrm{H}_{2} / \mathrm{O}_{2}$ and (d) $\mathrm{H}_{2} /$ Air at $150-250^{\circ} \mathrm{C}$ under 3 bar without humidification.

Extended Data Figure 4 I Proton conductivity mechanisms. a-b, (a) p-PBI; Grotthus-type hopping mechanism via benzimidazole ring between $\mathrm{H}_{3} \mathrm{PO}_{4}$ molecules at below $180{ }^{\circ} \mathrm{C}$. (b) SAN-CeHP-PBI composite membrane; a surface/interfacial conduction via proton transfer between benzimidazole ring-cerium hydrogen phosphate and cerium hydrogen phosphate molecules at elevated high temperature of over $200^{\circ} \mathrm{C}$.

Extended Data Figure 5 I Structural change of PA-doped PBI membranes according to temperature. a, Membrane images of the $p$-PBI membrane, CeHP-PBI composite membrane, and SAN-CeHP-PBI composite membranes. b-c, Scanning electron microscope images of (b) 
before and (c) after $100 \mathrm{~h}$ of heating at $250{ }^{\circ} \mathrm{C}$ for all three samples. d, EDX mapping images after $100 \mathrm{~h}$ of heating at $250^{\circ} \mathrm{C}$ of Ce element for all three samples. e-g, Raman spectra of $p$ PBI membrane, CeHP-PBI composite membrane, and SAN-CeHP-PBI composite membrane at (e) $30{ }^{\circ} \mathrm{C}$ and (f) after de-doped at $30^{\circ} \mathrm{C}$.

Extended Data Figure 6 | Mechanical stability property of PBI membranes. a-b, Tensile property comparison (a) PA-doped and (b) De-doped among p-PBI membrane, CeHP-PBI composite membrane, and SAN-CeHP-PBI composite membrane

\section{Extended Data Figure 7 I Acidic proton mobility of the de-doped PBI membranes. a, NMR} quantitation of total ${ }^{31} \mathrm{P}$ signal among $\mathrm{H}_{3} \mathrm{PO}_{4}, \mathrm{HPO}_{4}, \mathrm{PO}_{4}$ phases normalized by weight of all three samples; filled symbol; PA-doped; unfilled: De-doped. $\mathbf{b}$, XRD profiles of De-doped $p$ PBI membrane, CeHP-PBI composite membrane, and SAN-CeHP-PBI composite membrane. c, Membrane images, scanning electron microscope images, and EDX mapping images of Ce element, the De-doped of $p$-PBI membrane, CeHP-PBI composite membrane, and SAN-CeHPPBI composite membrane. d-f, ${ }^{31} \mathrm{P}$ solid-state MAS NMR spectra of De-doped (d) $p$-PBI membrane, (e) CeHP-PBI composite membrane, and (f) SAN-CeHP-PBI composite membrane shown for all four samples as T rises. $\mathbf{h}-\mathbf{j},{ }^{1} \mathrm{H}$ solid-state MAS NMR spectra of De-doped (h) p-PBI membrane, (g) CeHP-PBI composite membrane, and (i) SAN-CeHP-PBI composite membrane and CeHP powder shown for all four samples as temperature rises.

Extended Data Figure 8 | Reversible SAN-CeHP-PBI. a-b, $i-V$ curve with $\mathrm{Pt} / \mathrm{C}\left(1.5 \mathrm{mg}_{\mathrm{Pt}} \mathrm{cm}^{-}\right.$ ${ }^{2}$ ) and (a) PA-doped SAN-CeHP-PBI composite membrane $(t=110 \mu \mathrm{m})$ and (b) Re-PA-doped SAN-CeHP-PBI composite membrane $(t=120 \mu \mathrm{m})$, soaked in water for 3 days and then 
immersed in $85 \%$ PA for 1 day at $30{ }^{\circ} \mathrm{C}$, using $\mathrm{H}_{2} /$ air with no backpressure at $150-250{ }^{\circ} \mathrm{C}$. c,

728

729 Long-term stability of Re-PA-doped SAN-CeHP-PBI composite membrane $(t=120 \mu \mathrm{m})$ with

$\mathrm{Pt} / \mathrm{C}\left(1.5 \mathrm{mg}_{\mathrm{Pt}} \cdot \mathrm{cm}^{-2}\right)$. The fuel cells were tested at a constant current density of $0.2 \mathrm{~A} \cdot \mathrm{cm}^{-2}$ at $250{ }^{\circ} \mathrm{C}$ in $\mathrm{H}_{2} /$ air under anhydrous conditions.

Extended Data Figure 9 | Effect of cerium content on the fuel cell performance of composite membranes. a-c, $\mathrm{H}_{2}$ /Air fuel cell performance, $i$-V curve with the various PAdoped SAN-CeHP-PBI composite membranes with 15, 35, 70 and $90 \mathrm{wt} \%$ Cerium precursor $(t=110 \mu \mathrm{m})$, with $\mathrm{Pt} / \mathrm{C}\left(2.0 \mathrm{mgt}_{\mathrm{Pt}} \mathrm{cm}^{-2}\right.$, BASF commercial electrode) no backpressure at (a) 150 , (b) 200 and (c) $250^{\circ} \mathrm{C}$.

\section{Extended Data Figure 10 | Electrochemical analysis of 35wt\% SAN-CeHP-PBI composite} membranes a-b, Electrochemical impedance spectroscopy of PA-doped 35wt\% SAN-CeHPPBI composite membranes before and after 7000 min operation at a current density of $0.2 \mathrm{~A} \cdot \mathrm{cm}^{-}$ 2 and measured (a) $0.85 \mathrm{~V}$ and (b) $0.6 \mathrm{~V}$

\section{Extended Data Figure 11 | Conceptual design of an integrated HT-PEMFC for power} generation systems. a, Properties of representative hydrogen carriers applicable to the onboard hydrogen storage system. Thermodynamic reaction temperature required for $>99 \%$ conversion with a reported range of kinetic reaction temperature range for $>60 \%$ conversion with varying catalysts in the literature and theoretical reaction enthalpy of hydrogen extraction reaction of the candidates with a proportion of extracted hydrogen required to provide the theoretical reaction heat. b, Theoretical energy efficiency comparison with low, hightemperature polymer electrolyte membrane fuel cells and direct liquid hydrogen carrier fuel 
751 cells as a source of liquid hydrogen carrier for electricity generation from fuel cells. c-d, (c)

752 Schematic diagram, and (d) image of the experimental system LHC (methanol and N-

753 ethylcarbazole) reforming or dehydrogenation in conjunction with a unit cell using PA-doped $75435 \mathrm{wt} \%$ SAN-CeHP-PBI composite membrane $(t=110 \mu \mathrm{m})$.

755

756

Extended Data Table 1 | Cell Performance of comparison of different types of fuel cells as

757

reported in the literature.

758

759

Extended Data Table 2 | Assignment of Raman signals of PA-doped and de-doped SAN-

760

CeHP-PBI

761

762

Extended Data Table 3 | Properties of representative hydrogen carriers applicable to on-

board hydrogen storage system. Thermodynamic reaction temperatures required for $>99 \%$ and $>95 \%$ of the degree of dehydrogenation $(\mathrm{DoDH})$ are estimated by either calculation or

765 from the literature. Literature data on kinetic reaction temperatures for over $60 \%$ conversion of 766 the reactant to hydrogen is listed, and the range denotes different DoDH with different catalysts. Moreover, the heat of reaction and reaction stoichiometry are listed. 


\section{Supplementary Files}

This is a list of supplementary files associated with this preprint. Click to download.

- Supplementaryinformationfinal.pdf

- GXMyDriveJGJGManuscripts2021NENERGY21081496Supplementaryinformationfinalrevised.pdf

- ExtendedDataFiguresfinal.docx

- ExtendedDataTablefinal.docx 